\title{
Assessment of Ambient Air Toxics and Wood Smoke Pollution among Communities in Sacramento County
}

\author{
Steven G. Brown ${ }^{1, *}$, Janice Lam Snyder ${ }^{2}$, Michael C. McCarthy ${ }^{1}$, Nathan R. Pavlovic ${ }^{1}$ (D), \\ Stephen D'Andrea ${ }^{2}$, Joseph Hanson ${ }^{3}$, Amy P. Sullivan ${ }^{4}$ and Hilary R. Hafner ${ }^{1}$ \\ 1 Sonoma Technology, Inc., Petaluma, CA 95494, USA; mmccarthy@sonomatech.com (M.C.M.); \\ npavlovic@sonomatech.com (N.R.P.); hilary@sonomatech.com (H.R.H.) \\ 2 Sacramento Metropolitan Air Quality Management District (SMAQMD), Sacramento, CA 95814, USA; \\ JLam@airquality.org (J.L.S.); SDAndrea@airquality.org (S.D.) \\ 3 Meta Research, Inc., Sacramento, CA 95811, USA; Jhanson2@gmail.com \\ 4 Atmospheric Science Department, Colorado State University, Fort Collins, CO 80521, USA; \\ Amy.Sullivan@ColoState.EDU \\ * Correspondence: sbrown@sonomatech.com; Tel.: +1-707-665-9900
}

Received: 25 January 2020; Accepted: 4 February 2020; Published: 8 February 2020

\begin{abstract}
Ambient air monitoring and phone survey data were collected in three environmental justice (EJ) and three non-EJ communities in Sacramento County during winter 2016-2017 to understand the differences in air toxics and in wood smoke pollution among communities. Concentrations of six hazardous air pollutants (HAPs) and black carbon $(\mathrm{BC})$ from fossil fuel $\left(\mathrm{BC}_{\mathrm{ff}}\right)$ were significantly higher at $\mathrm{EJ}$ communities versus non-EJ communities. $\mathrm{BC}$ from wood burning $\left(\mathrm{BC}_{\mathrm{wb}}\right)$ was significantly higher at non-EJ communities. Correlation analysis indicated that the six HAPs were predominantly from fossil fuel combustion sources, not from wood burning. The HAPs were moderately variable across sites (coefficient of divergence (COD) range of 0.07 for carbon tetrachloride to 0.28 for $\mathrm{m}$ - and p-xylenes), while $\mathrm{BC}_{\mathrm{ff}}$ and $\mathrm{BC}_{\mathrm{wb}}$ were highly variable (COD values of 0.46 and 0.50$)$. The $\mathrm{BC}_{\mathrm{wb}}$ was well correlated with levoglucosan $\left(R^{2}\right.$ of 0.68 to 0.95$)$, indicating that $\mathrm{BC}_{\mathrm{wb}}$ was a robust indicator for wood burning. At the two permanent monitoring sites, wood burning comprised 29-39\% of the fine particulate matter $\left(\mathrm{PM}_{2.5}\right)$ on nights when $\mathrm{PM}_{2.5}$ concentrations were forecasted to be high. Phone survey data were consistent with study measurements; the only significant difference in the survey results among communities were that non-EJ residents burn with indoor devices more often than EJ residents.
\end{abstract}

Keywords: community air monitoring; black carbon; wood smoke; air toxics

\section{Introduction}

Wood smoke from residential burning is the largest source of wintertime particulate matter with aerodynamic diameter less than 2.5 microns $\left(\mathrm{PM}_{2.5}\right)$ emissions in the Sacramento, California, area, accounting for more than 50 percent of direct wintertime $\mathrm{PM}_{2.5}$ emissions [1]. Ambient pollution studies have also indicated that wood smoke is a major source of wintertime $\mathrm{PM}_{2.5}$ in Sacramento [2,3]. In Sacramento, this wintertime source of $\mathrm{PM}_{2.5}$ is particularly important; residential burning emissions typically occur in the evening or overnight, when they can be trapped in the shallow boundary layer that often forms in the Sacramento Valley. The resultant high-concentration $\mathrm{PM}_{2.5}$ events over the course of an evening can have acute health impacts [4,5], and exposure to wood burning emissions have been linked to health effects [5-7].

Wood smoke is a mixture of organic carbon and black carbon (BC), secondarily formed organic mass, and a wide range of gaseous species [8-11]. Wood smoke includes toxics such as formaldehyde, 
acetaldehyde, and acetonitrile $[12,13]$ as well as acrolein, polycyclic organic matter (POM), benzene, and dioxins [14,15], most of which are listed among the Environmental Protection Agency's (EPA) 30 Urban Air Toxics of Concern and are leading drivers of risk nationally [16]. Wood smoke from residential biomass burning differs from other pollutant sources in that it can be more localized than urban- or regional-scale pollutants such as ammonium nitrate, sulfate, or organic matter.

While there are thousands of chemicals emitted from residential biomass burning, unique chemicals are emitted from the combustion of wood lignin, namely, levoglucosan and other anhydrous sugars; therefore, levoglucosan was used as the main tracer for wood burning emissions. Levoglucosan is emitted during combustion of wood cellulose [17], and its emissions, relative to total emitted PM, can vary by fuel type and burning condition [18]. Levoglucosan may be oxidized in the atmosphere [19,20], but is relatively stable compared to other co-emitted compounds and is emitted from biomass burning in relative abundance, making it a commonly used wood smoke tracer [21,22]. In addition to direct filter-based measurements of levoglucosan, multi-channel Magee Scientific Aethalometers have been used to determine black carbon from wood burning $\left(\mathrm{BC}_{\mathrm{wb}}\right)$ and from fossil fuel combustion $\left(\mathrm{BC}_{\mathrm{ff}}\right)$ [23]; this method has been used widely in Europe and at a handful of locations in the United States [24-29].

Pollution can be higher in environmental justice (EJ) areas which are typically lower-income areas with a higher proportion of minority residents compared to non-EJ areas [30-33]. The US EPA defines EJ as the fair treatment and meaningful involvement of all people regardless of race, color, national origin, or income with respect to the development, implementation, and enforcement of environmental laws, regulations, and policies. The EPA has developed a tool, EJ Screen, that produces EJ indices for each census block in the US by combining environmental indicators, such as proximity to freeways, with demographic indices such as income level. In Sacramento, multiple communities are in the highest 5\% EJ Index nationally for both $\mathrm{PM}_{2.5}$ and cancer risk. This study focused on three such communities-South Natomas, Arden, and South Sacramento-and paired them with nearby non-EJ communities-T Street, Del Paso Manor, and Colonial Heights. Since wood smoke from residential burning is the largest single source of wintertime $\mathrm{PM}_{2.5}$ in Sacramento, and is typically due to local rather than urban- or regional-scale sources, we investigated the levels of $\mathrm{PM}_{2.5}$, hazardous air pollutants (HAPs), and wood smoke contributions to HAPs in these EJ and non-EJ communities, as well as the burning behavior of residents in these communities.

\section{Methods}

\subsection{Study Design and Site Selection}

Ambient air was monitored in three EJ and three non-EJ communities. The EJ communities were determined using the EPA's EJ Screen tool [34]. In EJ Screen, a demographic index is combined with an environmental index to determine an EJ Index for each US census block, yielding a relative rank for each census block in the United States. The demographic index uses the average of an income level factor and a racial minority factor. Specifically, income level is the number or percent of a block group's population in households where the household income is less than or equal to twice the federal poverty level, and the minority factor is the percent of individuals in a census block who list their racial status as a race other than white alone and/or list their ethnicity as Hispanic or Latino. The demographic indexes count each indicator as adding to the overall potential susceptibility of the population in a block group and assumes that the demographic indicators have equal and additive impacts. The $\mathrm{PM}_{2.5}$ was used as the environmental index which in EJ Screen is a fusion of annual average monitored data and modelled data. The $\mathrm{PM}_{2.5}$ concentration in each census block is estimated by the EPA's Office of Research and Development using a Bayesian space-time downscaling fusion model approach [34,35]. Finally, the EJ index for each census block is determined via the product of three terms multiplied together:

EJ Index $=($ environmental indicator $) \times($ demographic index for block group demographic index for US) $\times$ (population for block group) 
This results in a rank of the EJ Index for each US census block relative to all other census blocks. A higher EJ index indicates more potential for exposure/risk/proximity to certain facilities and/or a higher percentage minority population. Here, we identified communities with an EJ Index for $\mathrm{PM}_{2.5}$ in the highest $10 \%$ nationally as EJ locations, and those in the lowest $50 \%$ EJ Index as non-EJ locations; see Figure 1 for a map of the area, communities, and monitoring locations. Two existing permanent monitoring sites located in non-EJ communities were used at Del Paso Manor and T Street. To facilitate comparison between EJ and non-EJ communities, two EJ communities with similar characteristics near Del Paso Manor and T Street were identified. The Arden community (EJ) was paired with Del Paso Manor (non-EJ), less than 2 miles away, while the South Natomas community (EJ) was paired with T Street (non-EJ), less than 5 miles away. South Sacramento was selected as an additional EJ community, since there is limited air quality monitoring in the area and multiple census blocks in the community ranked in the top $10 \%$ of the national EJ Index for $\mathrm{PM}_{2.5}$. The nearby community (within 5 miles) of Colonial Heights was selected as the non-EJ community to pair with the South Sacramento community. Sacramento Metropolitan Air Quality Management District (SMAQMD) then conducted public outreach through local community groups, neighborhood associations, and its Board Members and staff in a search of volunteers to host monitoring equipment.

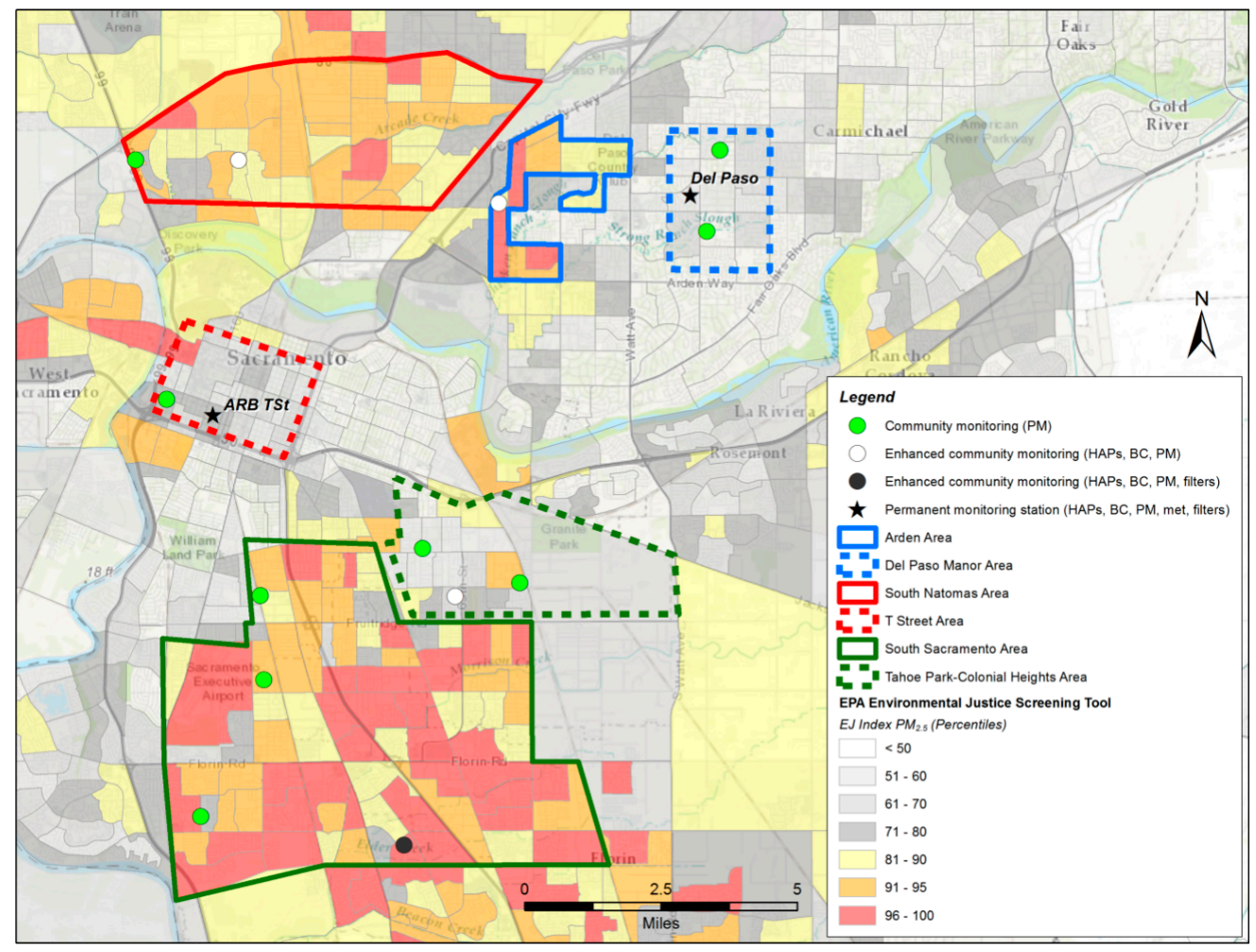

Figure 1. The Sacramento County communities where monitoring was conducted, the monitoring locations and pollutants monitored, and the Environmental Justice Index for $\mathrm{PM}_{2.5}$ from EPA's EJ Screen. HAPs: hazardous air pollutants. BC: black carbon. PM: particulate matter.

The HAPs and BC were measured at one site in each of the six communities. Quartz fiber filter samples for quantifying levoglucosan were collected at Del Paso Manor, T Street, and South Sacramento. PM was measured at all sites using low-cost sensors; details can be found in Mukherjee et al. [36]. Details of the sampling and analytical methods are provided in subsequent sections and are summarized in Table 1. In addition to ambient air monitoring, a phone survey was conducted to characterize what indoor burning devices are used and how often people burn with these devices in the EJ and non-EJ communities where the ambient sampling occurred. Data from the ambient measurements and survey were then compared; methods for this comparison are discussed after the discussion of air sampling and analytical methods. 
Table 1. Measurements conducted during the study period of 1 December 2016 through 31 January 2017.

\begin{tabular}{|c|c|c|c|c|c|c|c|c|c|}
\hline Pollutant & Method & Resolution & Frequency & $\begin{array}{c}\text { Colonial } \\
\text { Heights } \\
\text { (Non-EJ) }\end{array}$ & $\begin{array}{c}\text { South } \\
\text { Sacramento } \\
\text { (EJ) }\end{array}$ & $\begin{array}{c}\text { T Street } \\
\text { (Non-EJ) }\end{array}$ & $\begin{array}{c}\text { South } \\
\text { Natomas (EJ) }\end{array}$ & $\begin{array}{c}\text { Del Paso } \\
\text { Manor } \\
\text { (Non-EJ) }\end{array}$ & Arden (EJ) \\
\hline $\begin{array}{c}\mathrm{BC}, \mathrm{BC}_{\mathrm{ff}}, \\
\mathrm{BC}_{\mathrm{wb}}\end{array}$ & Aethalometer & Hourly & Continuous & $\mathrm{x}$ & $x$ & $x$ & $x$ & $x$ & $x$ \\
\hline $\mathrm{PM}_{2.5}$ & AirBeam sensor & $1 \mathrm{~min}$ & Continuous & $x$ & $\mathrm{x}$ & $x$ & $x$ & $\mathrm{x}$ & $\mathrm{x}$ \\
\hline $\mathrm{PM}_{2.5}$ & Met One BAM & Hourly & Continuous & & & $x$ & & $x$ & \\
\hline $\mathrm{PM}_{2.5}$ & FRM R\&P 2025 & $24 \mathrm{~h}$ & Daily & & & $x$ & & $x$ & \\
\hline $\begin{array}{l}\text { Gaseous } \\
\text { HAPs }\end{array}$ & $\begin{array}{c}\text { Canister sample; } \\
\text { TO-15 }\end{array}$ & $12 \mathrm{~h}$ & Episodic & $x$ & $x$ & $x$ & $x$ & $x$ & $x$ \\
\hline $\begin{array}{l}\text { Levoglucosan, } \\
\text { OC, EC }\end{array}$ & $\begin{array}{l}\text { Filter collected } \\
\text { with mini-vol or } \\
\text { Thermo 2025i } \\
\text { filter sampler }\end{array}$ & $12 \mathrm{~h}$ & $\begin{array}{c}\text { Episodic, } \\
\text { coincident } \\
\text { with canister } \\
\text { samples }\end{array}$ & & $\mathrm{x}$ & $x$ & & $\mathrm{x}$ & \\
\hline $\begin{array}{l}\text { Wind speed, } \\
\text { direction, } \\
\text { temperature }\end{array}$ & $\begin{array}{l}\text { R.M. Young } \\
\text { company } \\
\text { (ultrasonic) }\end{array}$ & Hourly & Continuous & & & $x$ & & $x$ & \\
\hline
\end{tabular}

EJ: Environmental Justice community. BAM: beta-attenuation monitor. FRM: federal reference method. R\&P: Rupprecht \& Patashnick Co., Inc. OC: organic carbon. EC: elemental carbon. 


\subsection{Hazardous Air Pollutants Sampling and Analytical Methods}

The HAPs were collected at a site in each community using five-liter Summa stainless-steel canisters at each site. Samples were collected for four sequential $12 \mathrm{~h}$ durations starting at either 06:00 or 18:00 PST on days when forecasts indicated that $\mathrm{PM}_{2.5}$ concentrations would be high on a particular day. Daytime (06:00 or 18:00) and nighttime (18:00 to 06:00) samples were taken, since mobile source emissions are relatively higher in daytime, and residential wood burning emissions are higher in nighttime $[25,26,37]$. Thus, a comparison of daytime to nighttime concentrations can show which source type contributes more to ambient HAPs. The sample periods were 19-23 December, 29-30 December, 15-17 January, and 27-30 January. Ten collocated samples were collected at T Street. A total of either 23 or 24 samples were collected at each site, except for at T Street, where 12 samples were collected, 10 of which had collocated samples taken from side-by-side monitors.

Canisters were shipped to Eastern Research Group (ERG) for analysis by EPA Method TO-15 [38] using a gas chromatography-mass spectrometry (GC-MS) system. Gaseous target compounds included 1,3-butadiene, 2,2,4-trimethylpentane (also known as iso-octane), acetonitrile, acetylene, acrolein, acrylonitrile, benzene, carbon tetrachloride, ethylbenzene, $\mathrm{m}$ - and $\mathrm{p}$-xylenes, and toluene. These key compounds are among the highest contributors to cancer risk and hazard nationally [39,40]. In addition, many of these compounds are found in wood smoke $[7,13,41]$ and were targeted to examine the potential impact of wood smoke on local concentrations of air toxics. 2,2,4-Trimethylpentane was used as the tracer for fossil fuel combustion, as it is not found in wood smoke [42]. Method detection limits (MDLs) were unique to each canister. Each sample concentration was compared to the sample-specific MDL. Acrylonitrile was never detected in any samples at those detection limits, while all other target compounds were above detection limits in more than $95 \%$ of samples. Detection limits were typically below 30 parts per trillion (ppt) for most target HAP compounds. The HAP data were assessed to examine differences in concentrations spatially and temporally, and the HAP data were also compared to levoglucosan, $\mathrm{PM}_{2.5}$, and $\mathrm{BC}$ data to assess whether there were any covariates that would indicate similar emissions sources.

\subsection{Filter Collection and Laboratory Analysis}

Quartz fiber filters (47 mm, Pall Life Sciences) were collected at Del Paso Manor, T Street, and a South Sacramento site on a forecast basis, generally at the same time as the nighttime HAP samples (i.e., 18:00 to 06:00 PST). Filters were analyzed for organic carbon (OC), elemental carbon (EC), and levoglucosan. Two daytime (06:00 to 18:00 PST) filters were also collected at each of these three sites during January 2017 to evaluate the difference between daytime and nighttime wood smoke concentrations, since residential wood smoke emissions generally occur in the evening when ambient temperatures begin to decrease. At the Del Paso Manor and T Street sites, Thermo Scientific $2025 \mathrm{i}$ sequential filtration samplers were used, with a sampling rate of $16.7 \mathrm{~L} / \mathrm{min}$. At the South Sacramento site, an AirMetrics mini-vol sampler was used, with a sampling rate of $5 \mathrm{~L} / \mathrm{min}$. Sample flow was evaluated before and after each sampling event. Five collocated filters were collected at South Sacramento to evaluate precision. Prior to sampling, filters were pre-baked for $12 \mathrm{~h}$ at $500{ }^{\circ} \mathrm{C}$ to remove residual organic compounds.

Levoglucosan was determined using a Dionex DX-500 series ion chromatograph with detection via an ED-50/ED-50A electrochemical cell. This cell includes two electrodes: a $\mathrm{pH}-\mathrm{Ag} / \mathrm{AgCl}$ (silver/silver chloride) reference electrode and a "standard" gold working electrode. For the separation, a sodium hydroxide gradient and a Dionex CarboPac PA-1 column $(4 \times 250 \mathrm{~mm})$ were used. The complete run time was 59 min with an injection volume of $100 \mu \mathrm{L}$. More details on the method can be found in Sullivan et al. [43-45]. 


\subsection{Aethalometer Operations and Calculations}

Magee Scientific model AE33 Aethalometers were deployed at a site in each community to measure BC. The AE33 collects ambient aerosol onto a filter tape, and then every five minutes measures the absorbance of the material deposited on the tape at 7 wavelengths, ranging from 370 to $960 \mathrm{~nm}$. The BC concentration is from the $880 \mathrm{~nm}$ channel. While BC absorbs uniformly across all wavelengths at which absorbance is measured, brown carbon, which is produced by combustion of wood or other biomass, absorbs primarily in the lower wavelengths of the measured range [46,47]. A commonly used method is to assume that BC is only from wood burning and fossil fuel combustion, so that the difference in absorbance at the $470 \mathrm{~nm}$ and $960 \mathrm{~nm}$ wavelengths can be used to calculate the quantity of $\mathrm{BC}_{\mathrm{wb}}$ and $\mathrm{BC}_{\mathrm{ff}}$. This method assumes that there are no other sources of $\mathrm{BC}$ such as coal dust. In the Sacramento emissions inventory, there is little to no impact from coal combustion emissions, so mobile sources and wood burning emissions are the main sources of $\mathrm{BC}$.

To calculate $\mathrm{BC}_{\mathrm{wb}}$ and $\mathrm{BC}_{\mathrm{ff}}$, the model described by Sandradewi et al. [48] and summarized in the AE33 User Manual [49] was used. The method uses the concentration values calculated using the $470 \mathrm{~nm}$ and $960 \mathrm{~nm}$ wavelengths to estimate the percentage of $\mathrm{BC}$ from wood burning. Concentrations of $\mathrm{BC}_{\mathrm{wb}}$ and $\mathrm{BC}_{\mathrm{ff}}$ are then calculated by multiplying the $\mathrm{BC}$ value from the $880 \mathrm{~nm}$ channel by the percentages obtained in the previous step. The calculation is based on a model in which the total BC can be divided into pure black and pure brown carbon using the spectral dependence of the absorbing properties of each material. The spectral dependence is described by the Angstrom exponent $(\alpha)$. From the Beer-Lambert Law, the following equations can be obtained:

$$
\begin{aligned}
& \frac{b_{a b s}(470 \mathrm{~nm})_{f f}}{b_{a b s}(950 \mathrm{~nm})_{f f}}=\left(\frac{470}{950}\right)^{-\alpha_{f f}} \\
& \frac{b_{a b s}(470 \mathrm{~nm})_{w b}}{b_{a b s}(950 \mathrm{~nm})_{w b}}=\left(\frac{470}{950}\right)^{-\alpha_{w b}} \\
& b_{a b s}(\lambda)=b_{a b s}(\lambda)_{f f}+b_{a b s}(\lambda)_{w b}
\end{aligned}
$$

where $b_{a b s}(\lambda)_{x}$ is the absorption coefficient for the BC type $x$ (wb or ff) at wavelength $\lambda$ ( 470 or 950).

The Sandradewi method requires input values for the Angstrom exponents for pure black and pure brown carbon. For this study, an Angstrom component of 1 for the pure black carbon and a value of 2 for the pure brown carbon were used. These are the default values used by the Aethalometer [23,49] and have been widely used in the scientific literature [25]. Harrison et al. [50] points out that use of the Aethalometer model can have limitations, notably from uncertainty in the Angstrom exponent selected for wood smoke, and when other sources of BC aerosol impact a monitor, such as coal emissions; however, in Sacramento there are no other significant sources of $\mathrm{BC}$ except biomass burning and fossil fuel combustion. $\mathrm{Th}_{\mathrm{BC}} \mathrm{wb}$ measurements were compared to levoglucosan to assess the quality of the $\mathrm{BC}_{\mathrm{wb}}$ calculation.

\subsection{Routine $P M_{2.5}$ and Meteorological Measurements at Del Paso Manor and T Street}

Hourly $\mathrm{PM}_{2.5}$ mass and meteorological data were obtained from EPA's air quality system (AQS) for the pre-existing routine monitoring sites at Del Paso Manor and T Street. At both sites, a MetOne beta attenuation monitor (BAM) 1020 collected hourly $\mathrm{PM}_{2.5}$ data, and an R\&P 2025 sequential filter sampler was operated as the $24 \mathrm{~h}$ Federal Reference Method (FRM) for $\mathrm{PM}_{2.5}$ mass. The FRM filters were collected daily, and $\mathrm{PM}_{2.5}$ mass was determined by gravimetric analysis. Temperature, $\mathrm{RH}$, wind speed, and wind direction data were collected at both sites using R.M. Young instrumentation. Dew point was calculated from temperature and RH measurements. Instrumentation and operations at these sites followed national guidance set by EPA on operations and methods. Wind and temperature data were used for the analysis of BC data. Each site with Aethalometer and canister measurements was assigned meteorological data from the weather station closest to that monitoring site. The Arden 
and Del Paso Manor communities were closest to the Del Paso Manor weather station, while the T Street, South Natomas, South Sacramento, and Colonial Heights communities were closest to the T Street weather station.

\subsection{Data Analysis Methods}

\subsubsection{Statistical Methods}

Statistical methods used here included conditional bivariate probability function plots [51,52], notched box whisker plots, coefficient of divergence calculations, ratio:ratio plots, and Kruskal-Wallis rank sum tests. Unless otherwise noted, the term "significant" is used when the $p$-value of a Student's $t$-test is less than 0.05 , i.e., significant at a $95 \%$ confidence level.

To determine whether significant differences in measured concentrations of $B C, B C_{f f}$, and $B_{w b}$ existed across communities, a Kruskal-Wallis rank sum test was performed on HAP concentrations among the communities. The Kruskal-Wallis test was selected to assess how similar the distribution of data was among sites. Post-hoc Nemenyi tests were applied for pairwise comparisons of BC data between each community to determine which communities' measurements differed significantly from each other; this test is useful for determining whether multiple groups of data are similar or not when there is a large amount of data [53].

To identify potential sources of black carbon, a conditional bivariate probability function (CBPF) analysis [52] was used. A CBPF analysis is similar to conditional probability function (CPF) analysis which is commonly used to identify emission sources. In CPF analysis, wind direction sectors that have a high probability of pollutant concentrations greater than a selected percentile of the total data are identified. The CBPF analysis enhances this method by incorporating wind speed bins and wind direction. Specifically, where $m$ is the number of samples with a concentration greater than the specified percentile, $n$ is the total number of samples, $\theta$ is a wind direction sector, and $j$ is the wind speed interval, the following equation is used to determine CBPF.

$$
\mathrm{CBPF}=\frac{m_{\theta, j}}{n_{\theta, j}}
$$

The CBPF is able to determine whether certain combinations of wind speed and wind direction have a high probability of producing concentrations above the specified percentile of data. By providing a greater degree of granularity to the analysis, CBPF facilitates the identification of sources that might not be detected by traditional CPF and can also be used to evaluate the characteristics of a source.

The polarPlot function available in the openair R package [51,54] was used to perform CBPF analysis. The CBPF analyses were done for each site where an AE33 was deployed to collect $\mathrm{BC}$, $\mathrm{BC}_{\mathrm{wb}}$, and $\mathrm{BC}_{\mathrm{ff}}$ concentrations based on the 80th percentile of the concentrations of each pollutant. The calculations, including the 80th percentile threshold, were performed individually for each site, and radial plots displaying the probability of exceeding the 80th percentile relative to wind speed and direction were created.

Ratio:ratio plots were used to assess how individual species relationships changed as a function of known tracers of wood smoke ( $\left.\mathrm{BC}_{\mathrm{wb}}\right)$ and fossil fuel (2,2,4-trimethylpentane) combustion [42]. In a ratio:ratio plot, the ratio of two given species to another species is plotted on both the $x$ - and $y$-axis, e.g., benzene/2,2,4-trimethylpentane versus toluene/2,2,4-trimethylpentane. We examined all possible combinations of the $12 \mathrm{~h}$ HAPs relative to the wood smoke indicator $\mathrm{BC}_{\mathrm{wb}}$ or the mobile source indicator 2,2,4-trimethylpentane to determine under which indicator species the HAPs varied the most. Differences in how ratios change depending on the indicator species in the denominator can indicate which source (i.e., wood smoke or mobile sources) most affects the species in the numerator [55]. 


\subsubsection{Filter Data Analysis}

Multiple studies have examined how to best convert levoglucosan to total wood burning PM. Puxbaum et al. [56] provided a review from numerous laboratory tests and suggested using a factor of 7.35 to convert levoglucosan concentration to wood burning organic carbon concentrations for wood burning stoves in the United States based on source profiles from Fine [57]. This is similar to what other studies have used [58-60] and is within the typical range used elsewhere, e.g., 10 in Szidat et al. [61] and 11 in Fuller et al. [62]. In an extensive experiment in London, England, Crilley et al. [25] compared multiple conversion factors and found that the Puxbaum et al. [56] factor of 7.35 gave the best agreement compared to a radiocarbon approach. Therefore, the Puxbaum factor was used to determine wood burning PM concentrations as equal to $7.35 \times$ levoglucosan.

For each monitor site, a linear regression between $\mathrm{BC}_{\mathrm{wb}}$ and levoglucosan was calculated. To make this calculation, hourly $\mathrm{BC}_{\mathrm{wb}}$ measurements over the $12 \mathrm{~h}$ period when filter measurements were collected were averaged together. A y-intercept of 0 was assumed, since $\mathrm{BC}_{\mathrm{wb}}$ and levoglucosan are both from the same source and should thus trend together to zero [29,62]. The Pearson correlation coefficient for $\mathrm{BC}_{\mathrm{wb}}$ and levoglucosan was calculated at each site. The site with the highest correlation coefficient between $\mathrm{BC}_{\mathrm{wb}}$ and levoglucosan was used to develop the relationship between $\mathrm{BC}_{\mathrm{wb}}$ and wood smoke $\mathrm{PM}_{2.5}$.

\subsection{Phone Survey Methods}

During the study period of December 2016 through January 2017, Meta Research, Inc., conducted a phone survey of residents in the six communities where monitoring was conducted. The objectives of the survey were to: (1) assess wood burning behavior; (2) evaluate wood burning activity by type of device used to burn; and (3) compare wood burning activity between EJ and non-EJ communities. Telephone interviews were completed with 900 (444 EJ; 456 non-EJ) Sacramento County residents who owned a wood or pellet burning device (other than an outdoor barbecue) either inside or outside their home. Addresses in each community were matched with listed landline and mobile phone numbers, then selected at random for interviewing.

The margin of error associated with a sample of 900 completed interviews is $\pm 3.3 \%$ at the $95 \%$ confidence level. That is, there is a $95 \%$ chance that the true population parameters lie within $3.3 \%$ of the sample statistics. For example, if a response category to a question was chosen by $50 \%$ of sample respondents, there is a $95 \%$ chance that if the entire county population were surveyed, that same response category would be selected by $46.7-53.3 \%$ of all residents $(50 \% \pm 3.3 \%)$. For the EJ communities, with 444 completed interviews, the margin of error at the $95 \%$ confidence level is $\pm 4.7 \%$, while that for the non-EJ communities, with 456 completed interviews, is $\pm 4.6 \%$.

Most of the questions were asked in a closed-ended format which were categorized for quantitative analysis; responses to open-ended questions were not used in quantitative analysis. Interviews took approximately $8 \mathrm{~min}$ on average to administer. Respondents were screened for age (18+) and ownership of a wood or pellet burning device, and to confirm residency in Sacramento County. Interviewing took place from 2 December through 19 December 2016, and from 6 January through 22 January 2017. Surveys were not conducted on holidays because response rates are typically lower on those days. A full list of the survey questions is provided in the Supplementary Materials. From these questions, the types of burning devices used in each community, the fraction of homes with EPA-certified devices, the frequency of use of burning devices, the relative number of burn days, and basic demographic information were determined. The relative number of burn days was calculated by how often each respondent used a device, e.g., if a respondent used the device one day per week, the relative number of burn days per week would be 1 . 


\section{Results and Discussion}

\subsection{HAPs and Levoglucosan Precision}

The precision of HAP measurements was determined using ten collocated (i.e., same place, time, and method) samples at T Street. Precision was calculated using the following formula, where A and B are the concentrations from the two collocated samples.

$$
\text { Precision }(\%)=200 \times[|(\mathrm{A}-\mathrm{B})| /(\mathrm{A}+\mathrm{B})]
$$

The National Air Toxics Trends Station's (NATTS) goal for high-precision data is $\pm 15 \%$ [63]. As shown in Table 2, median precision was lower than 15\% for all pollutants except acrolein (40\%) and acrylonitrile (below detection). This information indicates that precision is sufficient to assess spatial variations of $>15 \%$ for all pollutants except acrolein. Acrolein is known to have potential analytical issues based on canister sampling work done by Eastern Research Group Inc. (ERG) and EPA [64]. Levoglucosan precision was assessed in a similar way using five collocated filter samples collected at South Sacramento. The average precision was $4 \%$, and the $R^{2}$ value of the collocated measurements when plotted on a scatter plot was 0.99 , indicating high precision.

Table 2. Collocated HAPs and levoglucosan sample results $\left(\mu \mathrm{g} / \mathrm{m}^{3}\right)$.

\begin{tabular}{|c|c|c|c|c|c|}
\hline Analyte & $\begin{array}{c}\text { Emissions } \\
\text { Sources }\end{array}$ & $\begin{array}{c}N \text { Collocated } \\
\text { Samples }\end{array}$ & $\begin{array}{c}\text { Median } \\
\text { Precision \% }\end{array}$ & $\begin{array}{c}\text { Average } \\
\text { Precision } \%\end{array}$ & $\begin{array}{c}\text { Average } \\
\text { Concentration }\end{array}$ \\
\hline $\begin{array}{l}\text { 2,2,4-Trimethylpentane } \\
\text { (iso-octane) }\end{array}$ & $\begin{array}{l}\text { Mobile source } \\
\text { tracer }\end{array}$ & 10 & 5.1 & 5.9 & 0.3 \\
\hline Acetylene & $\begin{array}{l}\text { Mobile source } \\
\text { tracer }\end{array}$ & 10 & 5.3 & 6.2 & 2.96 \\
\hline Benzene & Air toxic & 10 & 6.3 & 8.5 & 0.62 \\
\hline Carbon Tetrachloride & $\begin{array}{l}\text { Air toxic; } \\
\text { internal QC }\end{array}$ & 10 & 5.8 & 8.5 & 0.09 \\
\hline Toluene & $\begin{array}{l}\text { Combustion } \\
\text { indicator }\end{array}$ & 10 & 11.0 & 12.6 & 1.9 \\
\hline m- and p-Xylenes & $\begin{array}{l}\text { Combustion } \\
\text { indicator }\end{array}$ & 10 & 9.4 & 14.0 & 0.59 \\
\hline Ethylbenzene & Air toxic & 10 & 9.0 & 15.2 & 0.19 \\
\hline Acetonitrile & Air toxic & 10 & 12.7 & 17.2 & 0.14 \\
\hline 1,3-Butadiene & Air toxic & 10 & 12.1 & 18.2 & 0.17 \\
\hline Acrolein & Air toxic & 10 & 40.0 & 46.0 & 0.27 \\
\hline Acrylonitrile & Air toxic & 10 & $<\mathrm{MDL}$ & $<\mathrm{MDL}$ & $<\mathrm{MDL}$ \\
\hline Levoglucosan & Wood burning & 5 & $3.3 \%$ & $4.4 \%$ & 1.1 \\
\hline
\end{tabular}

MDL: method detection limit.

\subsection{Comparison of $B C_{w b}$ and Levoglucosan}

Levoglucosan is a unique tracer for wood burning. It is typically collected via multi-hour filter measurements, so it cannot be measured continuously; significant labor and equipment are required to collect and chemically analyze the filters. The Aethalometer provides a calculated value of wood burning on an hourly basis and can run with little maintenance at multiple sites but requires validation that the wood burning calculation is correct. With both filter and Aethalometer measurements collected at the Del Paso Manor, South Sacramento, and T Street sites, we assessed how Aethalometer BC $\mathrm{wb}_{\mathrm{w}}$ compared to $\mathrm{PM}_{2.5}$ from wood burning estimated from levoglucosan measurements. If $\mathrm{BC}_{\mathrm{wb}}$ has a strong relationship with levoglucosan, it can be used to determine wood burning PM concentrations from Aethalometer measurements. Levoglucosan was compared to $\mathrm{BC}_{\mathrm{wb}}$ concentrations when the filters were collected as shown in Figure 2. Correlations among the concentrations of the two species were generally high. At the Del Paso Manor site, which had the highest levoglucosan and therefore wood smoke concentrations, there was a very high correlation between levoglucosan and $\mathrm{BC}_{\mathrm{wb}}$ $\left(R^{2}=0.95\right)$. There were moderate correlations between $\mathrm{BC}_{\mathrm{wb}}$ and levoglucosan concentrations at the South Sacramento $\left(R^{2}=0.68\right)$ and T Street $\left(R^{2}=0.80\right)$ sites. 


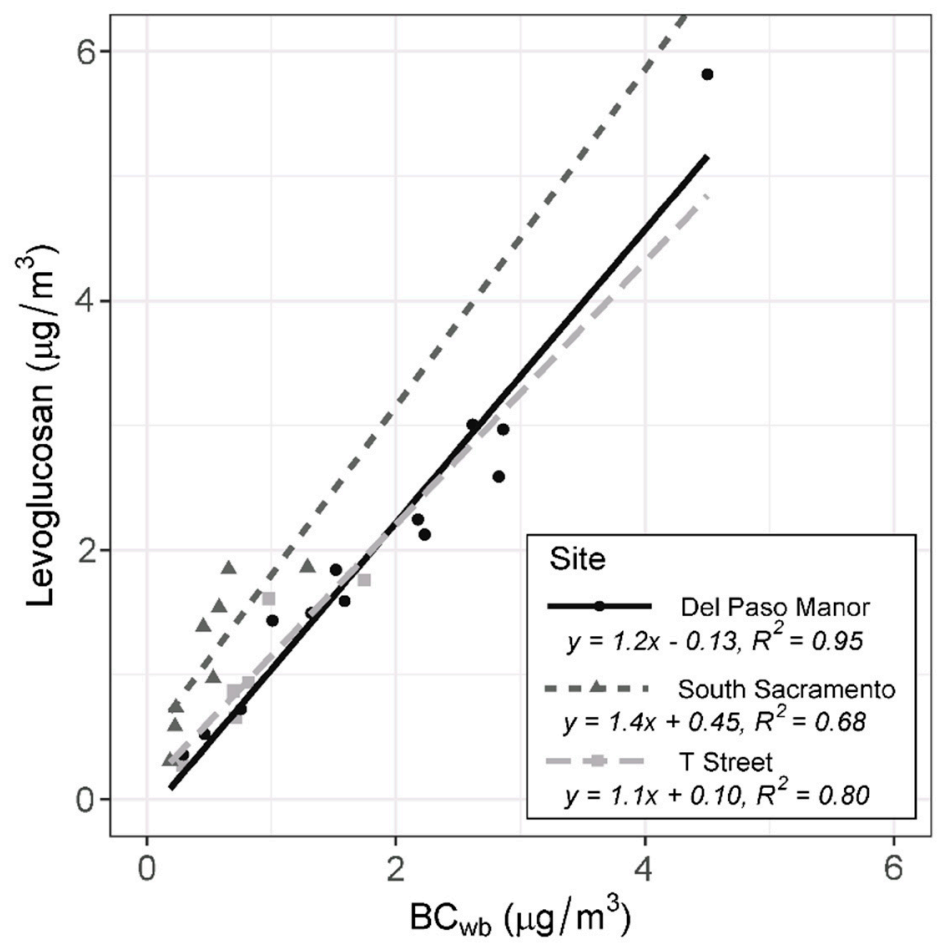

Figure 2. $\mathrm{BC}_{\mathrm{wb}}\left(\mu \mathrm{g} / \mathrm{m}^{3}\right)$ concentrations compared to levoglucosan $\left(\mu \mathrm{g} / \mathrm{m}^{3}\right)$ at the Del Paso Manor, South Sacramento, and T Street sites.

\subsection{Levoglucosan and Wood Burning PM Estimation}

Levoglucosan was used to estimate wood burning $\mathrm{PM}_{2.5}$ at the three sites where filters were collected. Filter results are summarized by site in Table 3. At each site, wood burning PM was calculated as described in Section 2. Figure 3 shows the amount of wood burning PM at each site by sample. At the Del Paso Manor and T Street sites, the fraction of $\mathrm{PM}_{2.5}$ from wood burning was also calculated using hourly $\mathrm{PM}_{2.5}$ measurements. Median levoglucosan concentrations across sites ranged from $0.86 \mu \mathrm{g} / \mathrm{m}^{3}$ at T Street to $1.84 \mu \mathrm{g} / \mathrm{m}^{3}$ at Del Paso Manor; the highest measured levoglucosan concentration was $5.8 \mu \mathrm{g} / \mathrm{m}^{3}$ at Del Paso Manor on the night of 19 December, when $\mathrm{PM}_{2.5}$ averaged $69 \mu \mathrm{g} / \mathrm{m}^{3}$ during the $12 \mathrm{~h}$ of sampling. Overall, levoglucosan and wood burning PM concentrations were highest at the Del Paso Manor site; concentrations at T Street and South Sacramento sites were similar. At the Del Paso Manor site, $39 \%$ of the $\mathrm{PM}_{2.5}$ (median value) during the filter sampling periods was from wood burning. At the T Street site, wood burning accounted for $29 \%$ of the PM concentrations (median value). At the South Sacramento site, the median concentration of wood burning $\mathrm{PM}_{2.5}$ was similar to that at the T Street site $\left(6.8 \mu \mathrm{g} / \mathrm{m}^{3}\right.$ at the South Sacramento site and $6.3 \mu \mathrm{g} / \mathrm{m}^{3}$ at the T Street site), and about half of the median concentration at the Del Paso Manor $\left(13.5 \mu \mathrm{g} / \mathrm{m}^{3}\right)$ site. These results suggest that wood burning emissions are higher around the Del Paso Manor site than around the other sites but are still responsible for a significant amount of the $\mathrm{PM}_{2.5}$ at $\mathrm{T}$ Street and South Sacramento.

Table 3. Summary of filter results $\left(\mu \mathrm{g} / \mathrm{m}^{3}\right)$ by site; Del Paso Manor and T Street are non-EJ and South Sacramento is an EJ site.

\begin{tabular}{lccc}
\hline \multicolumn{1}{c}{ Statistic } & Del Paso Manor & T Street & South Sacramento \\
\hline N 12 h samples (N night, day) & $13(11,2)$ & $13(11,2)$ & $10(8,2)$ \\
Median PM PM $_{2.5}$ & 39 & 24 & $\mathrm{n} / \mathrm{a}$ \\
Median levoglucosan & 1.84 & 0.86 & 0.93 \\
Median wood burning PM & 13.5 & 6.3 & 6.8 \\
\% PM from wood burning & $39 \%$ & $29 \%$ & n/a \\
\hline
\end{tabular}




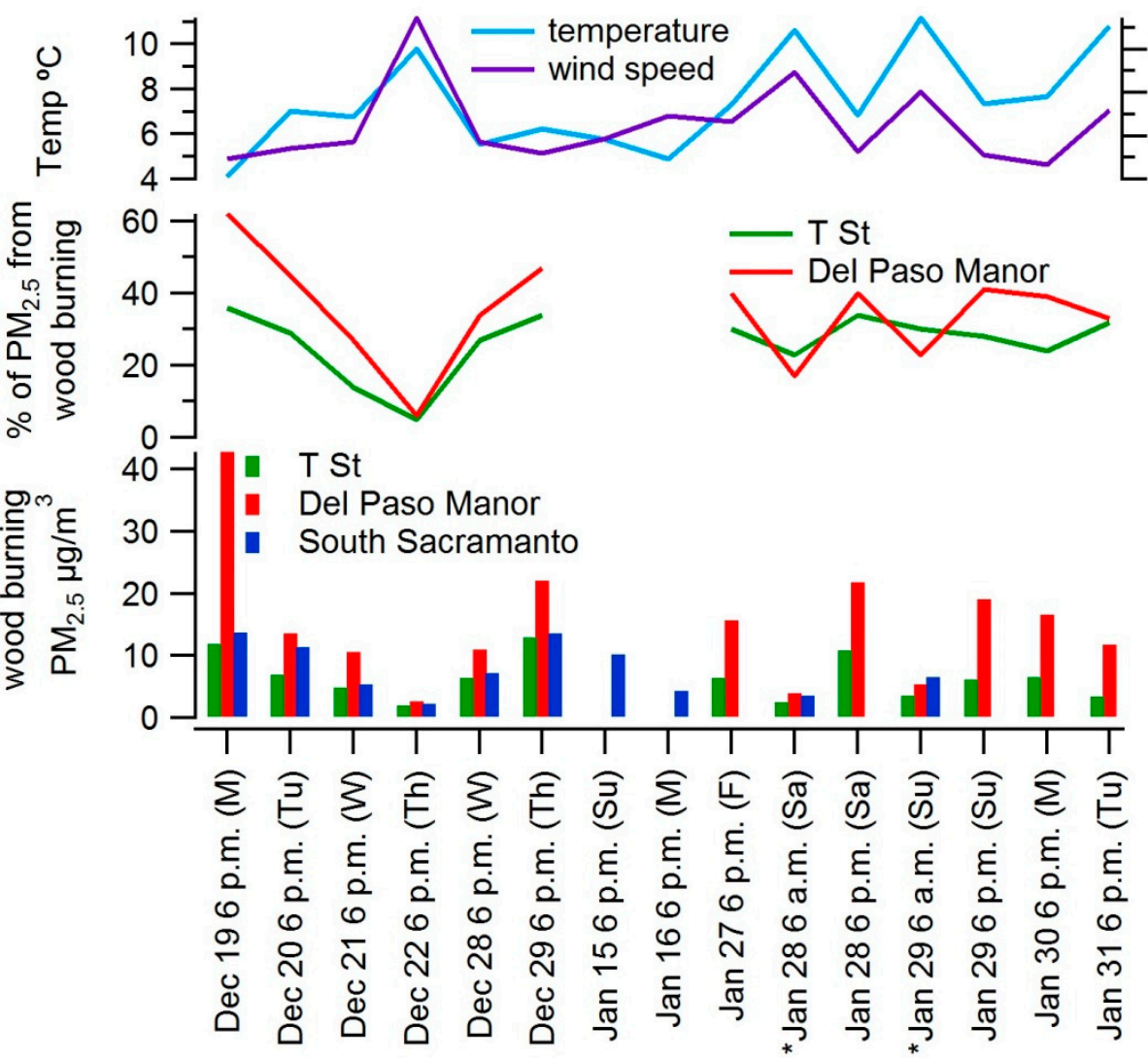

Figure 3. Calculated residential wood burning $\mathrm{PM}_{2.5}\left(\mu \mathrm{g} / \mathrm{m}^{3}\right)$ from levoglucosan measurements, percent of $\mathrm{PM}_{2.5}$ from residential wood burning and temperature and wind speed for each $12 \mathrm{~h}$ period when filters were collected; listed time indicates start time of sample and asterisks indicate the daytime samples. Temperature and wind speed data are shown for the T Street (T St) location. Percent of $\mathrm{PM}_{2.5}$ from residential wood burning is based on hourly measurements for $\mathrm{PM}_{2.5}$ at $\mathrm{T}$ Street and Del Paso Manor.

Nighttime concentrations were compared to two daytime samples collected at each site. As discussed later in the results of the phone survey, residential burning occurs predominantly in the evening or nighttime, not during the day, so levoglucosan found during the daytime is likely carried over from the prior night. On 28 and 29 January 2017, samples were collected at 06:00 and 18:00 PST at each site to provide a rough comparison of daytime concentrations to nighttime concentrations. Figure 4 shows the average of burning PM concentrations for the two daytime samples compared to two nighttime samples collected on 27, 28, and 29 January at the Del Paso Manor and T Street sites and on 15 and 16 January at the South Sacramento site. Del Paso Manor and T Street both had sequential samplers, enabling both nighttime and daytime filters to be collected, while South Sacramento had mini-vol samplers that collect only one filter at a time. Daytime samples were not collected at South Sacramento on 27-29 January because nighttime samples were collected. Nighttime concentrations of burning PM were four times higher than daytime concentrations at Del Paso Manor, roughly twice as high as daytime concentrations at the T Street site and roughly $50 \%$ higher than daytime concentrations at South Sacramento. Daytime concentrations of burning PM were similar at all three sites. While based on only a handful of samples, these results suggest that wood burning $\mathrm{PM}_{2.5}$ is well distributed across these three sites during the daytime and is elevated around Del Paso Manor during the nighttime. 


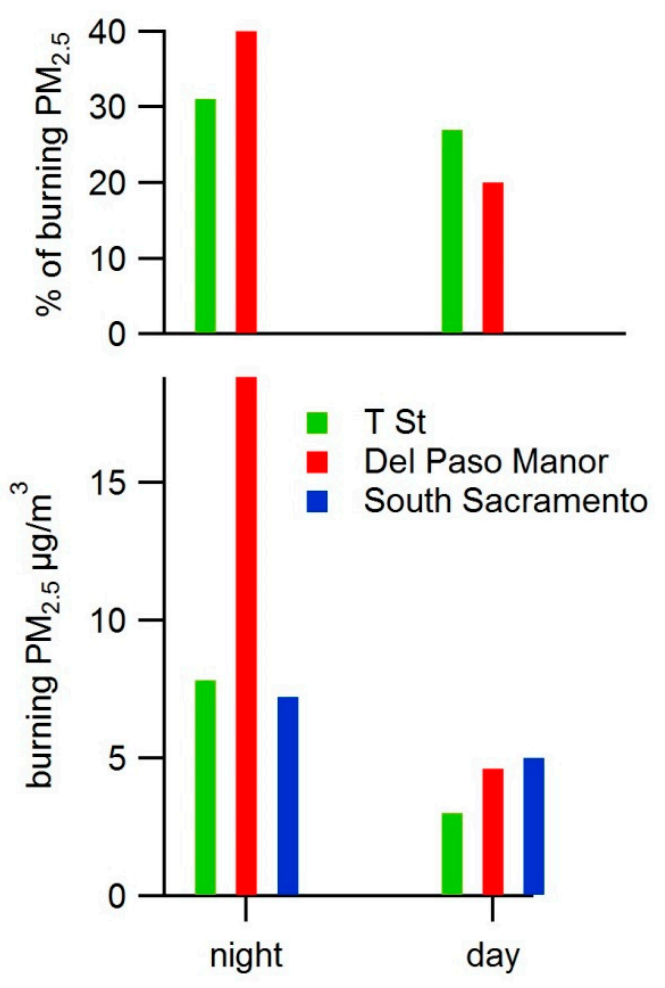

Figure 4. Average fraction of (top figure) and total (bottom figure) residential wood burning $\mathrm{PM}_{2.5}$ concentrations $\left(\mu \mathrm{g} / \mathrm{m}^{3}\right)$ during two daytime samples (28 and 29 January 2017 at the Del Paso Manor, T Street, and South Sacramento sites) and two nighttime samples (27 through 29 January 2017 at the Del Paso Manor and T Street sites and 15 and 16 January 2017 at the South Sacramento site).

\subsection{HAPs and BC Concentrations by Community}

Concentrations of 2,2,4-trimethylpentane, acrolein, benzene, ethylbenzene, $\mathrm{m}$ - and p-xylenes, and toluene were significantly higher $(p<0.05)$ at EJ communities compared to non-EJ communities. For example, benzene concentrations were $0.65 \mu \mathrm{g} / \mathrm{m}^{3}$ in EJ communities and $0.58 \mu \mathrm{g} / \mathrm{m}^{3}$ in non-EJ communities, on average. There was no significant difference between individual EJ/non-EJ site pairs for any species (Table 4$)$, likely due to the smaller overall sample size $(N=23$ at all locations except $T$ Street which had $N=12$ ) when comparing individual site locations. The HAPs that were significantly higher in EJ communities were typically from mobile sources, including 2,2,4-trimethylpentane, an indicator for mobile sources [42]. These results are consistent with EJ Screen which shows the three EJ communities in this study having EJ indices for $\mathrm{PM}_{2.5}$ in the highest (worst) decile of the entire United States, predominantly due to the fact of mobile source emissions. 
Table 4. MDL and site concentrations $\left(\mu \mathrm{g} / \mathrm{m}^{3}\right)$ for each HAP, and $\mathrm{p}$-value of significance between all EJ and non-EJ sites. Bold indicates significant differences at the $95 \%$ confidence level used by the Mann-Whitney U-test. Sites are ordered by non-EJ/EJ pair.

\begin{tabular}{|c|c|c|c|c|c|c|c|c|c|c|}
\hline Analyte & MDL & $\begin{array}{c}\text { Colonial } \\
\text { Heights } \\
\text { (Non-EJ) } \\
\end{array}$ & $\begin{array}{c}\text { South } \\
\text { Sacramento } \\
\text { (EJ) }\end{array}$ & $\begin{array}{c}\text { T Street } \\
\text { (Non-EJ) }\end{array}$ & $\begin{array}{c}\text { South } \\
\text { Natomas } \\
\text { (EJ) }\end{array}$ & $\begin{array}{c}\text { Del Paso } \\
\text { Manor } \\
\text { (Non-EJ) }\end{array}$ & Arden (EJ) & All Non-EJ & All EJ & $\begin{array}{l}p \text {-Value (Between } \\
\text { All Non-EJ and } \\
\text { All EJ Sites) }\end{array}$ \\
\hline 1,3-Butadiene & 0.026 & 0.166 & 0.163 & 0.167 & 0.222 & 0.154 & 0.224 & 0.160 & 0.202 & 0.12 \\
\hline 2,2,4-Trimethylpentane & 0.010 & 0.304 & 0.367 & 0.285 & 0.449 & 0.336 & 0.467 & 0.316 & 0.428 & 0.02 \\
\hline Acetonitrile & 0.051 & 0.127 & 0.121 & 0.153 & 0.161 & 0.146 & 0.140 & 0.141 & 0.141 & 0.33 \\
\hline Acetylene & 0.029 & 3.714 & 3.162 & 2.905 & 2.897 & 2.153 & 3.079 & 2.814 & 3.046 & 0.21 \\
\hline Acrolein & 0.120 & 0.234 & 0.290 & 0.317 & 0.260 & 0.235 & 0.339 & 0.249 & 0.296 & $<0.01$ \\
\hline Benzene & 0.021 & 0.562 & 0.593 & 0.598 & 0.776 & 0.585 & 0.798 & 0.580 & 0.722 & 0.05 \\
\hline Carbon Tetrachloride & 0.016 & 0.085 & 0.088 & 0.089 & 0.083 & 0.090 & 0.089 & 0.087 & 0.087 & 0.07 \\
\hline Ethylbenzene & 0.019 & 0.176 & 0.243 & 0.209 & 0.244 & 0.154 & 0.259 & 0.171 & 0.230 & 0.02 \\
\hline $\mathrm{m}$ - and p-Xylenes & 0.040 & 0.523 & 0.564 & 0.603 & 0.814 & 0.478 & 0.896 & 0.515 & 0.758 & $<0.01$ \\
\hline Toluene & 0.017 & 0.973 & 1.289 & 1.146 & 1.697 & 0.973 & 1.648 & 1.004 & 1.544 & $<0.01$ \\
\hline
\end{tabular}


The two likely sources of HAPs in this study-mobile sources and wood burning-peak at different times of a typical day; mobile source emissions peak in the morning during the commute hours with a secondary peak in the evening, while wood burning emissions peak in the evening hours and slowly decline into the early morning hours of the following day. Thus, having samples in both daytime and nighttime in the context of the diurnal $\mathrm{BC}, \mathrm{BC}_{\mathrm{wb}}$, and $\mathrm{BC}_{\mathrm{ff}}$ patterns allow for a comparison of whether HAPs are predominantly from mobile sources or wood burning; day/night changes in the stability of the atmosphere will also play a role in concentrations. For example, if HAP concentrations are higher in the daytime, mobile sources can be assumed to be a more important source of those HAPs than residential wood burning which predominantly occurs at night. The HAP samples were typically collected during four sequential $12 \mathrm{~h}$ daytime and nighttime periods, e.g., $12 \mathrm{~h}$ samples were taken starting at 18:00 PST, then at 06:00 PST and 18:00 PST the following day, and at 06:00 PST the day after that.

First, the day/night trends of carbon tetrachloride $\left(\mathrm{CCl}_{4}\right)$, a very long-lived HAP that is no longer emitted in the US, were examined. It was phased out as part of the Montreal Protocol to ban chlorofluorocarbons (CFCs) to repair the ozone hole; because it has a very long residence time in the atmosphere, it is very homogeneous, and concentrations should be approximately $0.085 \mathrm{ppb}$ everywhere in the United States $[39,65]$. The spatial and time-of-day variations should be minimal, and any deviations would indicate sampling and analytical imprecision. The samples measured during this study show no systematic bias across sites or time of day. This indicates high-quality sampling and analysis results.

In contrast to carbon tetrachloride, most of the HAPs showed large differences between daytime and nighttime concentrations. Statistical tests of daytime/nighttime differences are summarized in Supplementary Materials Table S1. Most sites measured higher concentrations in the daytime than in the nighttime for all species except carbon tetrachloride. Daytime concentrations of most HAPs were consistently higher than nighttime concentrations at the Arden, Del Paso Manor, South Natomas, and South Sacramento sites. Higher concentrations in the daytime indicate that the dominant sources of HAPs are more likely mobile source emissions than wood smoke emissions, consistent with the results shown earlier that HAPs have no statistically significant relationship with levoglucosan.

\subsection{BC Concentrations by Community}

The $\mathrm{BC}$ concentrations were compared among community sites to assess whether EJ or non-EJ sites measured higher concentrations. The $\mathrm{BC}$ concentrations by site are shown in Figure 5 and are also separated out by $\mathrm{BC}_{\mathrm{ff}}$ and $\mathrm{BC}_{\mathrm{wb}}$. Overall, $\mathrm{BC}$ and $\mathrm{BC}_{\mathrm{wb}}$ concentrations were significantly higher at the Del Paso Manor site when compared to the other sites, while $\mathrm{BC}_{\mathrm{ff}}$ was found to be generally similar across all sites (as shown in Supplementary Materials Tables S2-S4). Based on Mann-Whitney U-tests, $\mathrm{BC}$ and $\mathrm{BC}_{\mathrm{wb}}$ concentrations were higher at non-EJ sites compared to EJ sites at the $95 \%$ confidence level. The $\mathrm{BC}_{\mathrm{ff}}$ concentrations were not significantly different between the EJ and non-EJ sites. Significant site-to-site variations were observed: $B C$ concentrations at the South Natomas EJ site were significantly higher than the nearby non-EJ T Street site, and BC concentrations at the Colonial Heights and Del Paso Manor non-EJ sites were significantly higher than the South Sacramento and Arden EJ sites. 


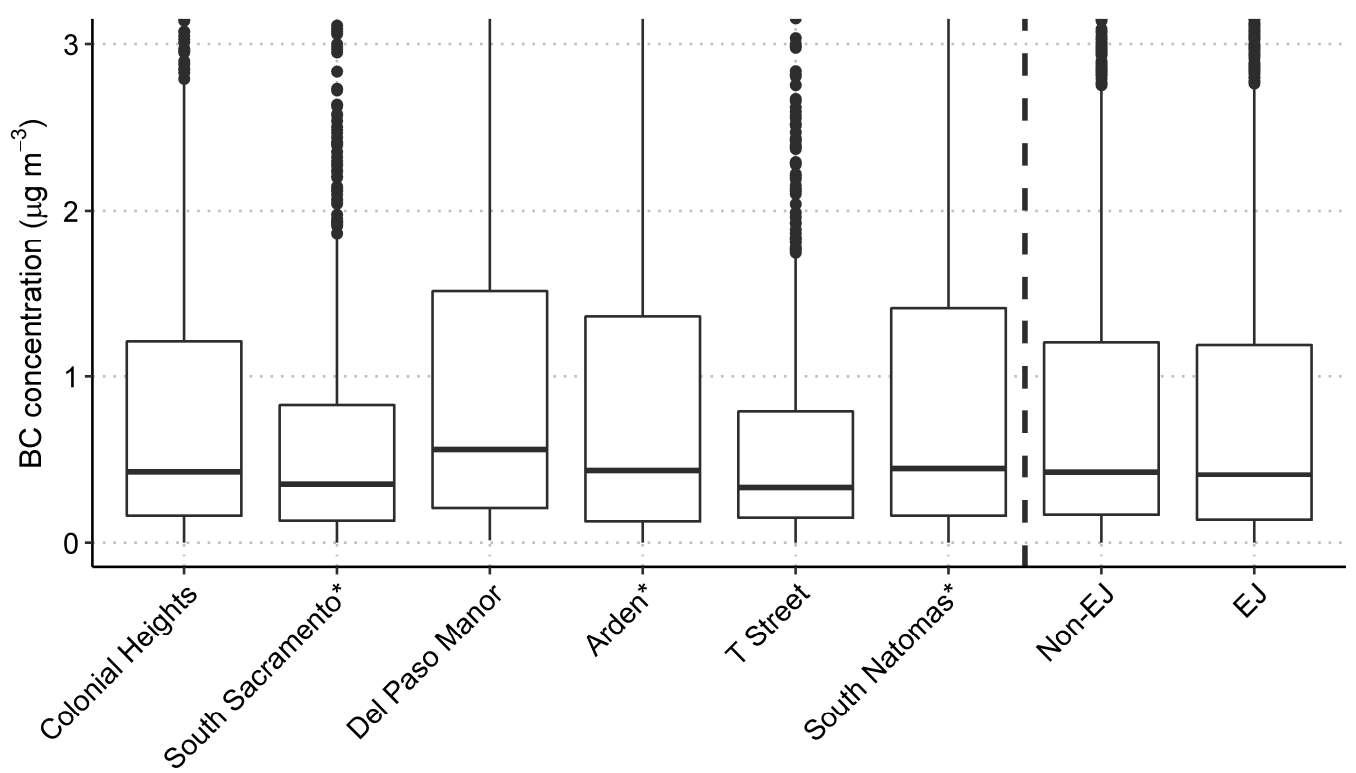

(a)

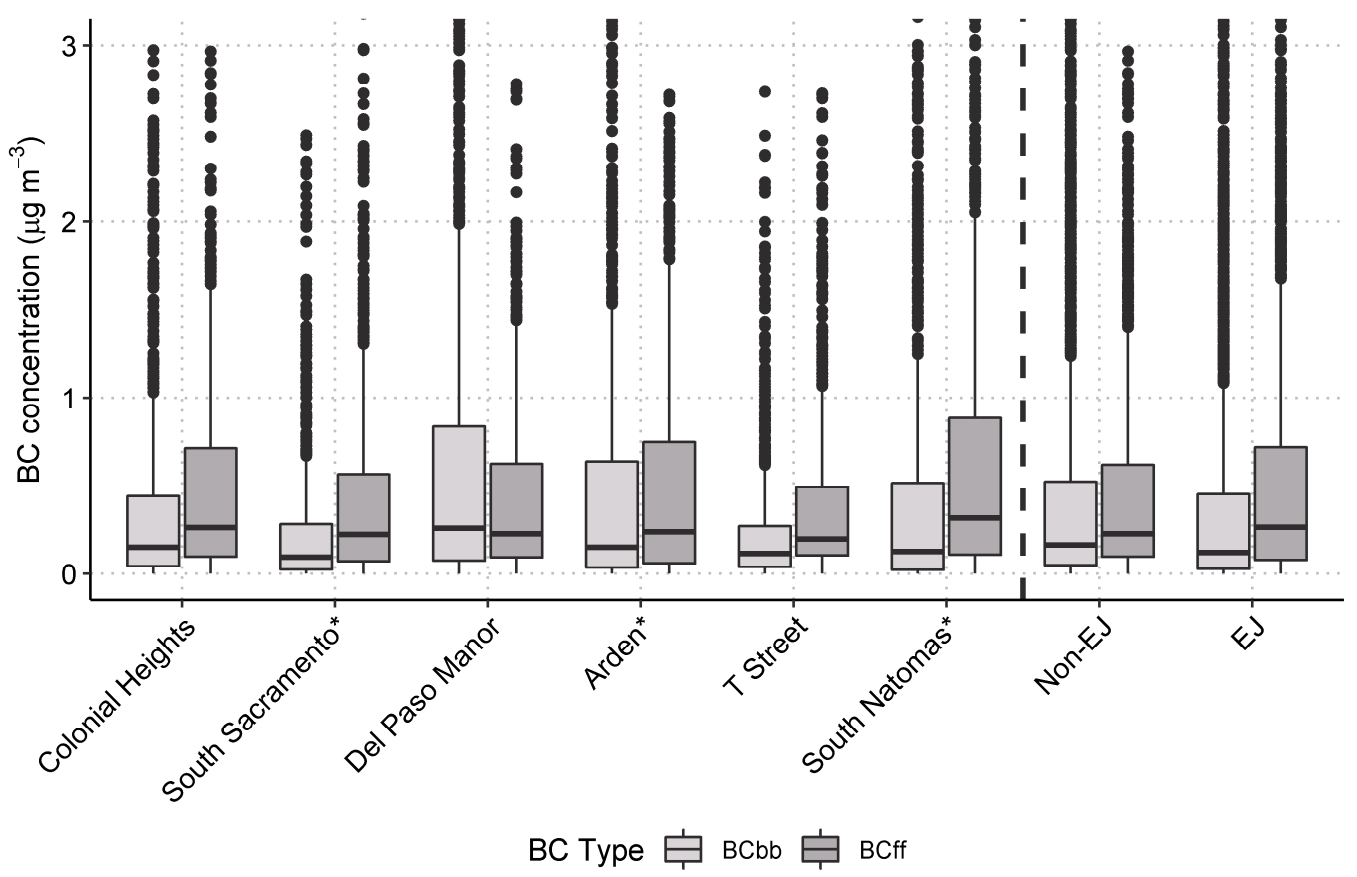

(b)

Figure 5. Notched box plot of concentrations by site and for all EJ and all non-EJ sites, from December 2016 through January 2017 for (a) BC and (b) $\mathrm{BC}_{\mathrm{wb}}$ and $\mathrm{BC}_{\mathrm{ff}}$. Data values above $3.1 \mu \mathrm{g} / \mathrm{m}^{3}$ are not shown. * Indicates an EJ site. Boxes are the interquartile range (IQR), and the notch is the median and $95 \%$ confidence interval about the median; the whiskers go to $1.5 \times \mathrm{IQR}$, and data beyond this are shown as individual points.

The diurnal and day-of-week variations in $\mathrm{BC}, \mathrm{BC}_{\mathrm{wb}}$, and $\mathrm{BC}_{\mathrm{ff}}$ were examined to investigate the temporal patterns of concentrations of these species (see Figures S1, S2 and Figure 6). Fossil fuel sources are expected be highest during the morning and evening commutes, and wood burning is expected to be highest during the evening. Day-of-week patterns may also exist, as there is typically less driving on Sundays compared to weekdays [66-69], and biomass burning indicator concentrations are often higher on weekends when residents tend to burn more [2,70-73]. 


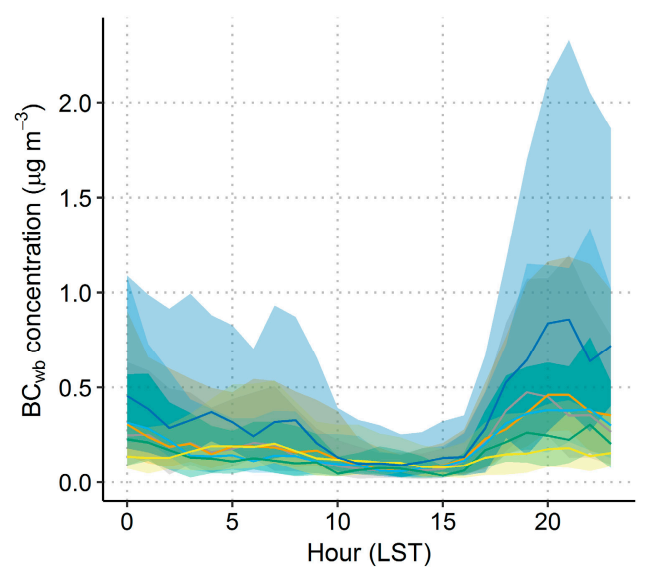

(a)

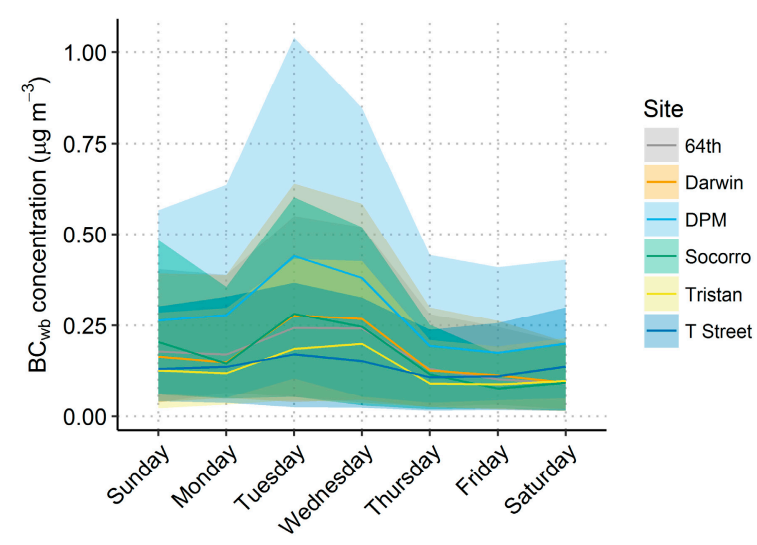

(b)

Figure 6. Diurnal (a) and day-of-week (b) plots for $\mathrm{BC}_{\mathrm{wb}}$ by site; the median is shown as a line, and the shading indicates the 95th confidence interval around the median. The 95th confidence interval was calculated based on the rank-ordered data values obtained from the binomial quantile function at probabilities of 0.025 and 0.975. DPM: Del Paso Manor.

In Sacramento, the T Street site has a typical urban diurnal pattern with elevated morning BC, while the other sites have a nighttime peak in $\mathrm{BC}$ that is higher than the $\mathrm{BC}$ morning peak. For all sites, $\mathrm{BC}_{\mathrm{wb}}$ was much higher at night than during the morning or daytime, consistent with expected wood burning patterns and phone survey results, discussed in detail later. There was also a large variation in nighttime $\mathrm{BC}$ and $\mathrm{BC}_{\mathrm{wb}}$ concentrations, as seen by the large confidence interval surrounding the median line in Figure 5. Overall, results suggest a strong effect from wood burning in the evening at all sites but $\mathrm{T}$ Street. The $\mathrm{BC}_{\mathrm{ff}}$ had a typical diurnal pattern of morning and evening peaks consistent with morning and evening rush hour traffic. The day-of-week patterns for $\mathrm{BC}, \mathrm{BC}_{\mathrm{wb}}$, and $\mathrm{BC}_{\mathrm{ff}}$ were unexpected with a large drop in all species concentrations between Wednesday and Thursday. Since only eight weeks of data were collected, variations were likely due to the presence of stochastic events such as rainfall (which would decrease concentrations) rather than consistent robust differences in emissions on Wednesday and Thursday compared to other days.

Hourly $\mathrm{BC}, \mathrm{BC}_{\mathrm{wb}}$, and $\mathrm{BC}_{\mathrm{ff}}$ measurements were combined with meteorological data to try to identify the likely source of these pollutants. The CBPF was used to identify wind speeds and directions associated with the highest quintile of concentrations. For all sites in this study, the highest quintile of concentrations of $\mathrm{BC}, \mathrm{BC}_{\mathrm{ff}}$, and $\mathrm{BC}_{\mathrm{wb}}$ occurred at very low wind speeds associated with stable and stagnant conditions (see Supplementary Materials Figure S3). At the T Street site, there were also high concentrations under high-speed winds from the northwest. However, closer examination revealed that this was caused by just $3 \mathrm{~h}$ in early December, during which $\mathrm{BC}_{\mathrm{wb}}$ concentrations were high and wind speeds were also high. It is unlikely that this result indicates a consistent source of $\mathrm{BC}_{\mathrm{wb}}$, and it is likely caused by a temporary, aberrant emission event. For $\mathrm{BC}_{\mathrm{ff}}$, the plots suggest that minor effects from fossil fuel sources exist south-southeast of the Colonial Heights, Del Paso Manor, and T Street sites which is the direction where freeways are located. Otherwise, CBPF analysis simply shows that high concentrations occurred with low wind speeds, rather than pointing to a specific source area or direction. 


\subsection{Inter-Comparisons Among Measurements}

The association of individual HAPs with $\mathrm{BC}_{\mathrm{wb}}$ was investigated using linear regression and ratio-ratio plots; correlation of a given $\mathrm{HAP}$ with $\mathrm{BC}_{\mathrm{wb}}$ would indicate that wood burning is a significant source of the HAP, while ratio-ratio plots can indicate which species may have a common source. The relationship of each HAP with 2,2,4-trimethylpentane was also examined, as 2,2,4-trimethylpentane is an indicator of fossil fuel combustion [42,74-76]; all results are presented in Table 5. Consistent across all six sites, $\mathrm{BC}_{\mathrm{wb}}$ and levoglucosan had little correlation with any $\mathrm{HAP}$ (i.e., $R^{2}<0.20$ ). This finding indicates that wood burning had little relation to HAPs at any site. As expected, carbon tetrachloride had little correlation with any other $\operatorname{HAP}\left(R^{2}<0.12\right)$, since its concentration levels are representative of global background concentrations. The HAPs that are typically from fossil fuel combustion (benzene, ethylbenzene, $\mathrm{m}$ - and p-xylenes, toluene, 1,3-butadiene, 2,2,4-trimethylpentane) had high correlations among themselves at every site $\left(R^{2}>0.70\right)$. This means that all of these species were from the same type of source, i.e., mobile source emissions.

Ratio:ratio plots were used to help understand the relative contribution of wood smoke and fossil fuel combustion to HAPs, OC, EC, and $\mathrm{PM}_{2.5}$. The relative importance of the two sources can be found by plotting the ratio of each species relative to tracers of wood smoke (represented by $\mathrm{BC}_{\mathrm{wb}}$ ) or fossil fuel combustion (represented by 2,2,4-trimethylpentane). High correlation in a ratio:ratio plot indicates that there is little impact from the applied tracer on the species in question, whereas low correlation indicates a high effect from the tracer. Examples are given in Supplementary Materials Figure S4, which highlights the benzene/toluene and acetylene/1,3-butadiene results. These figures indicate that there was little to no impact from wood burning on HAP concentrations. When divided by $\mathrm{BC}_{\mathrm{wb}}$, the HAPs were highly correlated on the ratio:ratio plots, but when divided by 2,2,4-trimethylpentane, the results clustered together tightly. These relationships indicate that a singular source of emissions dominated the species shown in the figures. Similar results were seen for most of the hydrocarbons (benzene, toluene, ethylbenzene, acetylene, m- and p-xylenes, and 1,3-butadiene). However, the oxygenated, nitrogenated, and chlorinated compounds, such as acetonitrile and acrolein, did not display this characteristic relationship when divided by either $\mathrm{BC}_{\mathrm{wb}}$ or 2,2,4-trimethylpentane, indicating that these compounds were not associated with $\mathrm{BC}_{\mathrm{wb}}$ or 2,2,4-trimethylpentane or were not measured due to the difficulty in measuring such compounds via canisters. 
Table 5. Matrix of median correlation coefficient $\left(R^{2}\right)$ of HAPs, PM, and filter measurements (where available) across all six monitoring sites. Correlations greater than 0.70 are shown in bold.

\begin{tabular}{|c|c|c|c|c|c|c|c|c|c|c|c|c|c|c|}
\hline Parameters & Acetonitrile & Acetylene & Acrolein & BC & $\mathrm{BC}_{\mathrm{ff}}$ & $\mathrm{BC}_{\mathrm{wb}}$ & Benzene & $\mathrm{CCl}_{4}$ & Ethylbenzene & $\begin{array}{c}\mathrm{m}, \mathrm{p}- \\
\text { Xylene }\end{array}$ & Toluene & $\begin{array}{c}1,3- \\
\text { Butadiene }\end{array}$ & iso-octane & Levoglucosan \\
\hline Acetonitrile & N/A & 0.17 & 0.03 & 0.10 & 0.09 & 0.07 & 0.47 & 0.01 & 0.36 & 0.33 & 0.35 & 0.37 & 0.36 & 0.21 \\
\hline Acetylene & 0.17 & N/A & 0.00 & 0.11 & 0.05 & 0.12 & 0.53 & 0.12 & 0.46 & 0.43 & 0.43 & 0.54 & 0.43 & 0.07 \\
\hline Acrolein & 0.03 & 0.00 & N/A & 0.07 & 0.05 & 0.06 & 0.02 & 0.06 & 0.00 & 0.00 & 0.00 & 0.02 & 0.00 & 0.11 \\
\hline $\mathrm{BC}$ & 0.10 & 0.11 & 0.07 & N/A & 0.71 & 0.84 & 0.10 & 0.00 & 0.10 & 0.08 & 0.09 & 0.08 & 0.11 & 0.85 \\
\hline $\mathrm{BC}_{\mathrm{ff}}$ & 0.09 & 0.05 & 0.05 & 0.71 & N/A & 0.31 & 0.06 & 0.01 & 0.04 & 0.03 & 0.03 & 0.06 & 0.05 & 0.05 \\
\hline $\mathrm{BC}_{\mathrm{wb}}$ & 0.07 & 0.12 & 0.06 & 0.84 & 0.31 & N/A & 0.09 & 0.00 & 0.11 & 0.09 & 0.10 & 0.06 & 0.11 & 0.88 \\
\hline Benzene & 0.47 & 0.53 & 0.02 & 0.10 & 0.06 & 0.09 & N/A & 0.03 & 0.80 & 0.78 & 0.84 & 0.87 & 0.78 & 0.17 \\
\hline $\mathrm{CCl}_{4}$ & 0.01 & 0.12 & 0.06 & 0.00 & 0.01 & 0.00 & 0.03 & N/A & 0.06 & 0.06 & 0.06 & 0.08 & 0.07 & 0.00 \\
\hline Ethylbenzene & 0.36 & 0.46 & 0.00 & 0.10 & 0.04 & 0.11 & 0.80 & 0.06 & N/A & 0.97 & 0.90 & 0.67 & 0.90 & 0.15 \\
\hline $\mathrm{m}$ - and p-Xylene & 0.33 & 0.43 & 0.00 & 0.08 & 0.03 & 0.09 & 0.78 & 0.06 & 0.97 & N/A & 0.85 & 0.68 & 0.85 & 0.13 \\
\hline Toluene & 0.35 & 0.43 & 0.00 & 0.09 & 0.03 & 0.10 & 0.84 & 0.06 & 0.90 & 0.85 & N/A & 0.72 & 0.91 & 0.17 \\
\hline 1,3-Butadiene & 0.37 & 0.54 & 0.02 & 0.08 & 0.06 & 0.06 & 0.87 & 0.08 & 0.67 & 0.68 & 0.72 & N/A & 0.65 & 0.11 \\
\hline iso-octane & 0.36 & 0.43 & 0.00 & 0.11 & 0.05 & 0.11 & 0.78 & 0.07 & 0.90 & 0.85 & 0.91 & 0.65 & N/A & 0.16 \\
\hline Levoglucosan & 0.21 & 0.07 & 0.11 & 0.85 & 0.05 & 0.88 & 0.17 & 0.00 & 0.15 & 0.13 & 0.17 & 0.11 & 0.16 & N/A \\
\hline
\end{tabular}




\subsection{Phone Survey Results and Comparison to Ambient Measurements}

Overall, the survey results show no significant differences between EJ and non-EJ communities in the type of device owned, fraction of homes burning with fireplaces, fraction of homes burning day and night, fraction of homes burning only at night, or fraction of homes with EPA-certified burning devices. The only significant differences are that homes in non-EJ communities burn with an indoor device more often than homes in EJ communities do and, thus, have a higher relative number of burn days than EJ communities. Specifically, the most commonly owned device was an indoor fireplace, owned by 79-80\% of all respondents in non-EJ and EJ communities; other devices, such as pellet stoves, accounted for less than $10 \%$ of responses. Those respondents who do burn with any device do so between one and two days per week. This frequency increases with the more devices a respondent owns. Of all respondents owning an indoor fireplace, those in non-EJ communities burn significantly more than those in EJ communities ( 0.35 and 0.23 burn days per week, respectively). Among respondents who burn with fireplaces, those in non-EJ communities are burning significantly more often than respondents in EJ communities (1.83 and 1.20 days per week, respectively).

Table 6 summarizes the survey results and ambient $\mathrm{HAPs}$ and $\mathrm{BC}_{\mathrm{wb}}$ results. Non-EJ communities have more burning device usage than EJ communities and, thus, a significantly higher relative number of burn days. This difference in the number of burn days likely means there are more emissions from wood burning in non-EJ communities which corresponds with the significantly higher observed $\mathrm{BC}_{\mathrm{wb}}$ in non-EJ communities. However, HAPs have an opposite relationship; for example, in the EJ communities where less wood burning occurs than in non-EJ communities, concentrations of multiple HAPs are higher. These results support all other analyses of the ambient data showing that wood burning has little impact on ambient HAP concentrations.

Table 6. Summary of survey results by EJ and non-EJ area, plus average concentrations of HAPs and $\mathrm{BC}_{\mathrm{wb}}\left(\mu \mathrm{g} / \mathrm{m}^{3}\right)$ by EJ and non-EJ area. Bold indicates significant differences at the $95 \%$ confidence level via the Mann-Whitney U-test; "question" indicates the survey question from which the data are derived (see Supplementary Materials for the list of questions).

\begin{tabular}{|c|c|c|}
\hline Metric & EJ & Non-EJ \\
\hline Fraction of homes with fireplace (question S3) & 80 & 79 \\
\hline Fraction of homes with any indoor device (question S3) & 91 & 89 \\
\hline Fraction of homes with wood or pellet stove (question S3) & 7 & 8 \\
\hline Fraction of homes with only outdoor burning (question S3) & 7 & 5 \\
\hline Fraction of homes with outdoor and indoor burning (question S3) & 92 & 91 \\
\hline Relative burn days with indoor fireplace (question $\mathrm{S} 3 \times 4.0 \mathrm{a} ; \times 4.1 \mathrm{a}$ ) & 0.27 & 0.43 \\
\hline Relative burn days with wood or pellet stove (question $\mathrm{S} 3 \times 4.2 \mathrm{a}$ ) & 0.48 & 0.7 \\
\hline Relative burn days with any indoor device (question $\mathrm{S} 3 \times 4.0,4.1,4.2$ ) & 0.31 & 0.48 \\
\hline Of households that burn, fraction of homes burning at night with indoor fireplace (question $4.0 \mathrm{~b}$ ) & 67 & 79 \\
\hline Of households that burn, fraction of homes burning day with indoor fireplace (question 4.0b) & 10 & 9 \\
\hline Of households that burn, fraction of homes burning day and night with indoor fireplace (question $4.0 \mathrm{~b}$ ) & 19 & 9 \\
\hline Of households that burn, fraction of homes burning at night with fireplace (question $\mathrm{S} 3 \times 4.0 \mathrm{~b}$ ) & 76 & 57 \\
\hline $\begin{array}{l}\text { Of households that burn, fraction of homes burning at night with wood or pellet stove } \\
\text { (question } \mathrm{S} 3 \times 4.0 \mathrm{~b} \text { ) }\end{array}$ & $\mathrm{n} / \mathrm{a}$ & n/a \\
\hline Fraction of homes burning with certified device (question $4.0 \mathrm{c}$ ) & 34 & 28 \\
\hline Fraction of homes burning indoor fireplace (questions 5.2 and 5.4) & 28 & 38 \\
\hline Fraction of homes burning on "Check Before You Burn" days (question 5.2 and 5.4) & 46 & 47 \\
\hline 1,3-Butadiene $\mu \mathrm{g} / \mathrm{m}^{3}$ & 0.18 & 0.16 \\
\hline 2,2,4-Trimethylpentane $\mu \mathrm{g} / \mathrm{m}^{3}$ & 0.37 & 0.31 \\
\hline Acetonitrile $\mu \mathrm{g} / \mathrm{m}^{3}$ & 0.14 & 0.14 \\
\hline Acetylene $\mu \mathrm{g} / \mathrm{m}^{3}$ & 2.99 & 2.92 \\
\hline Acrolein $\mu \mathrm{g} / \mathrm{m}^{3}$ & 0.27 & 0.26 \\
\hline Benzene $\mu \mathrm{g} / \mathrm{m}^{3}$ & 0.65 & 0.58 \\
\hline Carbon Tetrachloride $\mu \mathrm{g} / \mathrm{m}^{3}$ & 0.09 & 0.09 \\
\hline Ethylbenzene $\mu \mathrm{g} / \mathrm{m}^{3}$ & 0.20 & 0.18 \\
\hline $\mathrm{m}$ - and $\mathrm{p}$-Xylenes $\mu \mathrm{g} / \mathrm{m}^{3}$ & 0.64 & 0.53 \\
\hline Toluene $\mu \mathrm{g} / \mathrm{m}^{3}$ & 1.34 & 1.03 \\
\hline $\mathrm{BC}_{\mathrm{wb}} \mu \mathrm{g} / \mathrm{m}^{3}$ & 0.41 & 0.48 \\
\hline
\end{tabular}




\section{Conclusions}

In this first detailed community monitoring study during the winter in Sacramento County, we found that concentrations of six HAPs (benzene, toluene, ethylbenzene, m- and p-xylenes, 2,2,4-trimethylpentane, and acrolein) and $\mathrm{BC}_{\mathrm{ff}}$ were significantly higher at EJ communities than at non-EJ communities. Even though wood smoke emissions can contribute to HAPs, results from this study consistently showed that wood burning has little influence on the ambient levels of HAPs and that fossil fuel combustion was the main source of HAPs. The $\mathrm{BC}_{\mathrm{wb}}$ had a very high correlation with collocated measurements of the wood burning tracer levoglucosan ( $R^{2}$ across three sites of 0.68 to 0.95$)$, on the high end of reported literature values, indicating that $\mathrm{BC}_{\mathrm{wb}}$ was a robust indicator for wood burning in Sacramento. Thus, Aethalometer $\mathrm{BC}_{\mathrm{wb}}$ data could be used from all sites to assess wood burning contributions. Wood burning accounted for $29-39 \%$ of the nighttime $\mathrm{PM}_{2.5}$ at the two sites with hourly $\mathrm{PM}_{2.5}$ and filter measurements (T Street and Del Paso Manor). The $\mathrm{BC}_{\mathrm{wb}}$ concentrations were significantly higher at non-EJ communities than at EJ communities. As shown in the phone survey results, the higher $\mathrm{BC}_{\mathrm{wb}}$ concentrations in non-EJ communities were mostly likely due to the more burning with indoor fireplaces in the non-EJ communities. Wood burning was not a significant source of HAPs. The HAPs and $\mathrm{BC}_{\mathrm{ff}}$ were higher in EJ communities compared to non-EJ communities, indicating mobile source emissions were likely higher in EJ communities.

Supplementary Materials: The following are available online at http://www.mdpi.com/1660-4601/17/3/1080/s1. Figure S1: Diurnal and day-of-week plots for BC by site. Figure S2: Diurnal and day-of-week plots for $\mathrm{BC}_{\mathrm{ff}}$ by site. Figure S3: CBPF plots for the highest quintile of $\mathrm{BC}, \mathrm{BC}_{\mathrm{ff}}$, and $\mathrm{BC}_{\mathrm{wb}}$ concentrations. Figure S4: Ratio:ratio plots of (top) benzene and toluene and (bottom) acetylene and 1,3-butadiene, divided by BCwb (left) and 2,2,4-trimethylpentane (right). Table S1: Summary of Kruskal-Wallis estimates of distribution differences between daytime and nighttime concentrations of HAPs. Table S2: Significance of post-hoc Nemenyi tests for pairwise multiple comparisons for BC between each community. Table S3: Significance of post-hoc Nemenyi tests for pairwise multiple comparisons between each community for $\mathrm{BC}_{\mathrm{wb}}$. Table S4: Significance of post-hoc Nemenyi tests for pairwise multiple comparisons between each community for $\mathrm{BC}_{\mathrm{ff}}$.

Author Contributions: Conceptualization, S.G.B., J.L.S.; methodology, S.G.B., J.L.S., S.D., J.H., A.P.S.; validation, M.C.M., N.R.P., S.D.; formal analysis, S.G.B., M.C.M., N.R.P.; resources, J.L.S., H.R.H.; data curation, M.C.M., N.R.P., J.H., A.P.S., S.G.B.; writing-original draft preparation, S.G.B., M.C.M., N.R.P., J.H.; writing-review and editing, H.R.H., J.L.S., S.D.; visualization, M.C.M., N.R.P.; project administration, J.L.S.; supervision, H.R.H.; funding acquisition, S.G.B., J.L.S. All authors have read and agreed to the published version of the manuscript.

Funding: Funding was provided by Sacramento Metropolitan Air Quality Management District (SMAQMD) and the EPA through a community air toxics grant (Grant Number: XA-99T33401-2).

Acknowledgments: The work presented here was supported by SMAQMD and STI field staff. Lori Kobza (SMAQMD) led the effort to recruit and work with local community groups and members to host the monitoring sites. Clinton MacDonald and Paul Roberts (STI) helped design the study. Justin Dumas (STI) helped designed and assembled the sensor sampling apparatuses. Dave Vaughn (STI) developed the VOC sampler system used. Daily $\mathrm{PM}_{2.5}$ forecasts were provided by STI staff and were funded by SMAQMD. Aleta Kennard (SMAQMD, retired) helped to write the grant proposal and design the study. Eastern Research Group (ERG) performed the HAP laboratory analyses.

Conflicts of Interest: The authors declare no conflict of interest.

\section{References}

1. California Air Resources Board. CEPAM: 2016 SIP—Standard Emission Tool. Available online: https: //www.arb.ca.gov/app/emsinv/fcemssumcat/fcemssumcat2016.php (accessed on 18 July 2018).

2. Hasheminassab, S.; Daher, N.; Saffari, A.; Wang, D.; Ostro, B.D.; Sioutas, C. Spatial and temporal variability of sources of ambient fine particulate matter $\left(\mathrm{PM}_{2.5}\right)$ in California. Atmos. Chem. Phys. 2014, 14, 12085-12097. [CrossRef]

3. Kleeman, M.J.; Riddle, S.G.; Robert, M.A.; Jakober, C.A.; Fine, P.M.; Hays, M.D.; Schauer, J.J.; Hannigan, M.P. Source apportionment of fine $\left(\mathrm{PM}_{1.8}\right)$ and ultrafine $\left(\mathrm{PM}_{0.1}\right)$ airborne particulate matter during a severe winter pollution episode. Environ. Sci. Technol. 2009, 43, 272-279. [CrossRef] [PubMed]

4. Lighty, J.S.; Veranth, J.M.; Sarofim, A.F. Combustion aerosols: Factors governing their size and composition and implications to human health. J. Air Waste Manage. Assoc. 2000, 50, 1565-1618. [CrossRef] [PubMed] 
5. Barregard, L.; Sallsten, G.; Andersson, L.; Almstrand, A.-C.; Gustafson, P.; Andersson, M.; Olin, A.-C. Experimental exposure to wood smoke: Effects on airway inflammation and oxidative stress. Occup. Environ. Med. 2007, 65, 319-324. [CrossRef] [PubMed]

6. Laumbach, R.J.; Kipen, H.M. Respiratory health effects of air pollution: Update on biomass smoke and traffic pollution. J. Allergy Clin. Immunol. 2012, 129, 3-11. [CrossRef] [PubMed]

7. Naeher, L.P.; Brauer, M.; Lipsett, M.; Zelikoff, J.T.; Simpson, C.D.; Koenig, J.Q.; Smith, K.R. Woodsmoke health effects: A review. Inhal. Toxicol. 2007, 19, 67-106. [CrossRef] [PubMed]

8. Nolte, C.G.; Schauer, J.J.; Cass, G.R.; Simoneit, B.R.T. Highly polar organic compounds present in wood smoke and in the ambient atmosphere. Environ. Sci. Technol. 2001, 35, 1912-1919. [CrossRef]

9. Schmidl, C.; Marr, I.L.; Caseiro, A.; Kotianova, P.; Berner, A.; Bauer, H.; Kasper-Giebl, A.; Puxbaum, H. Chemical characterisation of fine particle emissions from wood stove combustion of common woods growing in mid-European Alpine regions. Atmos. Environ. 2008, 42, 126-141. [CrossRef]

10. Fine, P.M.; Cass, G.R.; Simoneit, B.R.T. Organic compounds in biomass smoke from residential wood combustion: Emissions characterization at a continental scale. J. Geophys. Res.-Atmos. 2002, 107. [CrossRef]

11. Kleeman, M.J.; Schauer, J.J.; Cass, G.R. Size and composition distribution of fine particulate matter emitted from wood burning, meat charbroiling, and cigarettes. Environ. Sci. Technol. 1999, 33, 3516-3523. [CrossRef]

12. Holzinger, R.; Warneke, C.; Hansel, A.; Jordan, A.; Lindinger, W.; Scharffe, D.H.; Schade, G.; Crutzen, P.J. Biomass burning as a source of formaldehyde, acetaldehyde, methanol, acetone, acetonitrile, and hydrogen cyanide. Geophys. Res. Lett. 1999, 26, 1161-1164. [CrossRef]

13. Gustafson, P.; Barregard, L.; Strandberg, B.; Sällsten, G. The impact of domestic wood burning on personal, indoor and outdoor levels of 1,3-butadiene, benzene, formaldehyde and acetaldehyde. J. Environ. Monit. 2007, 9, 23-32. [CrossRef] [PubMed]

14. McDonald, J.D.; Zielinska, B.; Fujita, E.M.; Sagebiel, J.C.; Chow, J.C.; Watson, J.G. Fine particle and gaseous emission rates from residential wood combustion. Environ. Sci. Technol. 2000, 34, 2080-2091. [CrossRef]

15. Schauer, J.J.; Kleeman, M.J.; Cass, G.R.; Simoneit, B.R.T. Measurement of emissions from air pollution sources. 3. $\mathrm{C}_{1}$ through $\mathrm{C}_{29}$ organic compounds from fireplace combustion of wood. Environ. Sci. Technol. 2001, 35, 1716-1728. [CrossRef]

16. McCarthy, M.C.; Hafner, H.R.; Chinkin, L.R.; Charrier, J.G. Temporal variability of selected air toxics in the United States. Atmos. Environ. 2007, 41, 7180-7194. [CrossRef]

17. Simoneit, B.R.T.; Schauer, J.J.; Nolte, C.G.; Oros, D.R.; Elias, V.O.; Fraser, M.P.; Rogge, W.F.; Cass, G.R. Levoglucosan, a tracer for cellulose in biomass burning and atmospheric particles. Atmos. Environ. 1999, 33, 173-182. [CrossRef]

18. Sullivan, A.P.; Holden, A.S.; Patterson, L.A.; McMeeking, G.R.; Kreidenweis, S.M.; Malm, W.C.; Hao, W.M.; Wold, C.E.; Collett, J.L., Jr. A method for smoke marker measurements and its potential application for determining the contribution of biomass burning from wildfires and prescribed fires to ambient $\mathrm{PM}_{2.5}$ organic carbon. J. Geophys. Res. 2008, 113, D22302. [CrossRef]

19. Hennigan, C.J.; Miracolo, M.A.; Engelhart, G.J.; May, A.A.; Presto, A.A.; Lee, T.; Sullivan, A.P.; McMeeking, G.R.; Coe, H.; Wold, C.E.; et al. Chemical and physical transformations of organic aerosol from the photo-oxidation of open biomass burning emissions in an environmental chamber. Atmos. Chem. Phys. 2011, 11, 7669-7686. [CrossRef]

20. Hennigan, C.J.; Sullivan, A.P.; Collett, J.L., Jr.; Robinson, A.L. Levoglucosan stability in biomass burning particles exposed to hydroxyl radicals. Geophys. Res. Lett. 2010, 37, L09806. [CrossRef]

21. Fraser, M.P.; Lakshmanan, K. Using levoglucosan as a molecular marker for the long-range transport of biomass combustion aerosols. Environ. Sci. Technol. 2000, 34, 4560-4564. [CrossRef]

22. Hoffmann, D.; Tilgner, A.; Iinuma, Y.; Herrmann, H. Atmospheric stability of levoglucosan: A detailed laboratory and modeling study. Environ. Sci. Technol. 2010, 44, 694-699. [CrossRef] [PubMed]

23. Drinovec, L.; Močnik, G.; Zotter, P.; Prévôt, A.S.H.; Ruckstuhl, C.; Coz, E.; Rupakheti, M.; Sciare, J.; Müller, T.; Wiedensohler, A.; et al. The "dual-spot" Aethalometer: An improved measurement of aerosol black carbon with real-time loading compensation. Atmos. Meas. Tech. 2015, 8, 1965-1979. [CrossRef]

24. Healy, R.M.; Sofowote, U.; Su, Y.; Debosz, J.; Noble, M.; Jeong, C.-H.; Wang, J.M.; Hilker, N.; Evans, G.J.; Doerksen, G. Ambient measurements and source apportionment of fossil fuel and biomass burning black carbon in Ontario. Atmos. Environ. 2017, 161, 34-47. [CrossRef] 
25. Crilley, L.R.; Bloss, W.J.; Yin, J.; Beddows, D.C.S.; Harrison, R.M.; Allan, J.D.; Young, D.E.; Flynn, M.; Williams, P.; Zotter, P.; et al. Sources and contributions of wood smoke during winter in London: Assessing local and regional influences. Atmos. Chem. Phys. 2015, 15, 3149-3171. [CrossRef]

26. Favez, O.; Cachier, H.; Sciare, J.; Sarda-Estève, R.; Martinon, L. Evidence for a significant contribution of wood burning aerosols to $\mathrm{PM}_{2.5}$ during the winter season in Paris, France. Atmos. Environ. 2009, 43, 3640-3644. [CrossRef]

27. Heringa, M.F.; DeCarlo, P.F.; Chirico, R.; Tritscher, T.; Dommen, J.; Weingartner, E.; Richter, R.; Wehrle, G.; Prévôt, A.S.H.; Baltensperger, U. Investigations of primary and secondary particulate matter of different wood combustion appliances with a high-resolution time-of-flight aerosol mass spectrometer. Atmos. Chem. Phys. 2011, 11, 5945-5957. [CrossRef]

28. Sandradewi, J.; Prévôt, A.S.H.; Alfarra, M.R.; Szidat, S.; Wehrli, M.N.; Ruff, M.; Weimer, S.; Lanz, V.A.; Weingartner, E.; Perron, N.; et al. Comparison of several wood smoke markers and source apportionment methods for wood burning particulate mass. Atmos. Chem. Phys. Discuss. 2008, 8, 8091-8118. [CrossRef]

29. Favez, O.; El Haddad, I.; Piot, C.; Boréave, A.; Abidi, E.; Marchand, N.; Jaffrezo, J.-L.; Besombes, J.-L.; Personnaz, M.-B.; Sciare, J.; et al. Inter-comparison of source apportionment models for the estimation of wood burning aerosols during wintertime in an Alpine city (Grenoble, France). Atmos. Chem. Phys. 2010, 10, 5295-5314. [CrossRef]

30. Miranda, M.L.; Edwards, S.E.; Keating, M.H.; Paul, C.J. Making the environmental justice grade: The relative burden of air pollution exposure in the United States. Inter. J. Environ. Res. Public Health 2011, 8, 1755-1771. [CrossRef]

31. Pope, R.; Wu, J.; Boone, C. Spatial patterns of air pollutants and social groups: A distributive environmental justice study in the Phoenix metropolitan region of USA. Environ. Manag. 2016, 58, 753-766. [CrossRef]

32. Chakraborty, J. Automobiles, air toxics, and adverse health risks: Environmental inequities in Tampa Bay, Florida. Ann. Assoc. Am. Geogr. 2009, 99, 674-697. [CrossRef]

33. Fisher, J.B.; Kelly, M.; Romm, J. Scales of environmental justice: Combining GIS and spatial analysis for air toxics in West Oakland, California. Health Place 2006, 12, 701-714. [CrossRef] [PubMed]

34. Berrocal, V.J.; Gelfand, A.E.; Holland, D.M. A spatio-temporal downscaler for output from numerical models. J. Agric. Biol. Environ. Stat. 2010, 15, 176-197. [CrossRef] [PubMed]

35. US Environmental Protection Agency. EJSCREEN Environmental Justice Mapping and Screening Tool: Technical Documentation; US EPA: Washington, DC, USA, 2017. Available online: https://www.epa.gov/ejscreen (accessed on 1 August 2017).

36. Mukherjee, A.D.; Brown, S.G.; McCarthy, M.C.; Pavlovic, N.R.; Snyder, J.L.; Andrea, S.D.; Hafner, H.R. Measuring spatial and temporal $\mathrm{PM}_{2.5}$ variations in Sacramento, California, communities using a network of low-cost sensors. Sensors 2019, 19, 4701. [CrossRef] [PubMed]

37. Allen, G.A.; Miller, P.J.; Rector, L.J.; Brauer, M.; Su, J.G. Characterization of valley winter woodsmoke concentrations in Northern NY using highly time-resolved measurements. Aerosol. Air Qual. Res. 2011, 11, 519-530. [CrossRef]

38. U.S. Environmental Protection Agency. Compendium of Methods for the Determination of Toxic Organic Compounds in Ambient Air: Compendium Method TO-15, 2nd ed.; Office of Research and Development, U.S. Environmental Protection Agency: Cincinnati, OH, USA, 1999.

39. McCarthy, M.C.; O’Brien, T.E.; Charrier, J.G.; Hafner, H.R. Characterization of the chronic risk and hazard of hazardous air pollutants in the United States using ambient monitoring data. Environ. Health Perspect. 2009, 117, 790-796. [CrossRef]

40. US Environmental Protection Agency. 2011 National Air Toxics Assessment (NATA); US EPA: Washington, DC, USA, 2015. Available online: https://www.epa.gov/national-air-toxics-assessment/2011-national-air-toxicsassessment (accessed on 17 December 2015).

41. Lee, S.; Baumann, K.; Schauer, J.J.; Sheesley, R.J.; Naeher, L.P.; Meinardi, S.; Blake, D.R.; Edgerton, E.S.; Russell, A.G.; Clements, M. Gaseous and particulate emissions from prescribed burning in Georgia. Environ. Sci. Technol. 2005, 39, 9049-9056. [CrossRef]

42. McCarthy, M.C.; Aklilu, Y.-A.; Brown, S.G.; Lyder, D.A. Source apportionment of volatile organic compounds measured in Edmonton, Alberta. Atmos. Environ. 2013, 81, 504-516. [CrossRef] 
43. Sullivan, A.P.; Frank, N.; Kenski, D.M.; Collett, J.L., Jr. Application of high-performance anion-exchange chromatography-pulsed amperometric detection for measuring carbohydrates in routine daily filter samples collected by a national network: 2. Examination of sugar alcohols/polyols, sugars, and anhydrosugars in the upper Midwest. J. Geophys. Res. 2011, 116, D08303. [CrossRef]

44. Sullivan, A.P.; Frank, N.; Onstad, G.; Simpson, C.D.; Collett, J.L., Jr. Application of high-performance anion-exchange chromatography-pulsed amperometric detection for measuring carbohydrates in routine daily filter samples collected by a national network: 1 . Determination of the impact of biomass burning in the upper Midwest. J. Geophys. Res. 2011, 116, D08302. [CrossRef]

45. Sullivan, A.; May, A.; Lee, T.; McMeeking, G.; Kreidenweis, S.; Akagi, S.; Yokelson, R.; Urbanski, S.; Collett, J.L., Jr. Airborne characterization of smoke marker ratios from prescribed burning. Atmos. Chem. Phys. 2014, 14, 11715-11747. [CrossRef]

46. Park, K.; Chow, J.C.; Watson, J.G.; Arnott, W.P.; Trimble, D.; Bowers, K.; Bode, R.; Petzold, A.; Hansen, A.D.A. Comparison of continuous and filter-based carbon measurments at the Fresno Supersite. J. Air Waste Manag. Assoc. 2006, 56. [CrossRef] [PubMed]

47. Jeong, C.H.; Hopke, P.K.; Kim, E.; Lee, D.W. The comparison between thermal-optical transmittance elemental carbon and Aethalometer black carbon measured at multiple monitoring sites. Atmos. Environ. 2004, 38, 5193-5204. [CrossRef]

48. Sandradewi, J.; Prévôt, A.S.H.; Szidat, S.; Perron, N.; Alfarra, M.R.; Lanz, V.A.; Weingartner, E.; Baltensperger, U. Using aerosol light absorption measurements for the quantitative determination of wood burning and traffic emission contributions to particulate matter. Environ. Sci. Technol. 2008, 42, 3316-3323. [CrossRef] [PubMed]

49. Magee Scientific. Aethalometer@Model AE33 User Manual, Version 1.54. Available online: http://group. mageesci.com/images/sampledata/AEdata/manual/AE33/AE33_UsersManual_Rev154.pdf (accessed on 1 March 2016).

50. Harrison, R.M.; Beddowsa, D.C.S.; Jones, A.M.; Calvo, A.; Alves, C.; Pio, C. An evaluation of some issues regarding the use of aethalometers to measure woodsmoke concentrations. Atmos. Environ. 2013, 80, 540-548. [CrossRef]

51. Carslaw, D.C.; Ropkins, K. openair-An R package for air quality data analysis. Environ. Model. Softw. 2012, 27-28, 52-61. [CrossRef]

52. Uria-Tellaetxe, I.; Carslaw, D.C. Conditional bivariate probability function for source identification. Environ. Model. Softw. 2014, 59, 1-9. [CrossRef]

53. Tzima, F.A.; Mitkas, P.A.; Voukantsis, D.; Karatzas, K. Sparse episode identification in environmental datasets: The case of air quality assessment. Expert Syst. Appl. 2011, 38, 5019-5027. [CrossRef]

54. Grange, S.K.; Lewis, A.C.; Carslaw, D.C. Source apportionment advances using polar plots of bivariate correlation and regression statistics. Atmos. Environ. 2016, 145, 128-134. [CrossRef]

55. Subramanian, R.; Donahue, N.M.; Bernardo-Bricker, A.; Rogge, W.F.; Robinson, A.L. Contribution of motor vehicle emissions to organic carbon and fine particle mass in Pittsburgh, Pennsylvania: Effects of varying source profiles and seasonal trends in ambient marker concentrations. Atmos. Environ. 2006, 40, 8002-8019. [CrossRef]

56. Puxbaum, H.; Caseiro, A.; Sanchez-Ochoa, A.; Kasper-Giebl, A.; Claeys, M.; Gelencser, A.; Legrand, M.; Preunkert, S.; Pio, C. Levoglucosan levels at background sites in Europe for assessing the impact of biomass combustion on the European aerosol background. J. Geophys. Res. 2007, 112, D23S05. [CrossRef]

57. Fine, P.M.; Cass, G.R.; Simoneit, B.R.T. Chemical characterization of fine particle emissions from the fireplace combustion of woods grown in the southern United States. Environ. Sci. Technol. 2002, 36, 1442-1451. [CrossRef] [PubMed]

58. Gelencser, A.; May, B.; Simpson, D.; Sánchez-Ochoa, A.; Kasper-Giebl, A.; Puxbaum, H.; Caseiro, A.; Pio, C.; Legrand, M. Source apportionment of $\mathrm{PM}_{2: 5}$ organic aerosol over Europe: Primary/secondary, natural/anthropogenic, and fossil/biogenic origin. J. Geophys. Res. 2007, 112, D23S04. [CrossRef]

59. Pio, C.; Cerqueira, M.; Harrison, R.M.; Nunes, T.; Mirante, F.; Alves, C.; Oliveira, C.; Sanchez de la Campa, A.; Artínano, B.; Matos, M. OC=EC ratio observations in Europe: Rethinking the approach for apportionment between primary and secondary organic carbon. Atmos. Environ. 2011, 45, 6121-6132. [CrossRef]

60. Brown, S.G.; Lee, T.; Roberts, P.T.; Collett, J.L., Jr. Wintertime residential biomass burning in Las Vegas, Nevada; marker components and apportionment methods. Atmosphere 2016, 7, 58. [CrossRef] 
61. Szidat, S.; Ruff, M.; Perron, N.; Wacker, L.; Synal, H.-A.; Hallquist, M.; Shannigrahi, A.S.; Yttri, K.E.; Dye, C.; Simpson, D. Fossil and non-fossil sources of organic carbon (OC) and elemental carbon (EC) in Göteborg, Sweden. Atmos. Chem. Phys. 2009, 9, 1521-1535. [CrossRef]

62. Fuller, G.W.; Tremper, A.H.; Baker, T.D.; Yttri, K.E.; Butterfield, D. Contribution of wood burning to $\mathrm{PM}_{10}$ in London. Atmos. Environ. 2014, 87 (Supplement C), 87-94. [CrossRef]

63. Battelle. Technical Assistance Document for the National Air Toxics Trends Stations Program, Revision 3; Prepared for: US Environmental Protection Agency, the Office of Air Quality Planning and Standards; Research Triangle Park, NC, October 2016. Available online: https://www3.epa.gov/ttnamti1/files/ambient/airtox/ NATTS\%20TAD\%20Revision\%203_FINAL\%20October\%202016.pdf (accessed on 30 October 2019).

64. Shelow, D.; Rice, J.; Jones, M.; Camalier, L.; Swift, J. Acrolein measurements. In Proceedings of the National Ambient Air Monitoring Conference, Nashville, TN, USA, 2-5 November 2009.

65. McCarthy, M.C.; Hafner, H.R.; Montzka, S.A. Background concentrations of 18 air toxics for North America. J. Air Waste Manag. Assoc. 2006, 56, 3-11. [CrossRef]

66. Valin, L.C.; Russell, A.R.; Cohen, R.C. Chemical feedback effects on the spatial patterns of the $\mathrm{NO}_{\mathrm{x}}$ weekend effect: A sensitivity analysis. Atmos. Chem. Phys. 2014, 14, 1-9. [CrossRef]

67. Yarwood, G.; Grant, J.; Koo, B.; Dunker, A.M. Modeling weekday to weekend changes in emissions and ozone in the Los Angeles basin for 1997 and 2010. Atmos. Environ. 2008, 42, 3765-3779. [CrossRef]

68. Blanchard, C.L.; Tanenbaum, S.; Lawson, D.R. Differences between weekday and weekend air pollutant levels in Atlanta; Baltimore; Chicago; Dallas-Fort Worth; Denver; Houston; New York; Phoenix; Washington, DC; and surrounding areas. J. Air Waste Manag. Assoc. 2008, 58, 1598-1615. [CrossRef] [PubMed]

69. Brown, S.G.; McCarthy, M.C.; DeWinter, J.L.; Vaughn, D.L.; Roberts, P.T. Changes in air quality at near-roadway schools after a major freeway expansion in Las Vegas, Nevada. J. Air Waste Manag. Assoc. 2014, 64, 1002-1012. [CrossRef] [PubMed]

70. Wang, Y.; Hopke, P.K.; Utell, M.J. Urban-scale spatial-temporal variability of black carbon and winter residential wood combustion particles. Aerosol. Air Qual. Res. 2011, 11, 473-481. [CrossRef]

71. Zhang, X.; Lin, Y.-H.; Srurratt, J.D.; Zotter, P.; Prévôt, A.S.H.; Weber, R.J. Light-absorbing soluble organic aerosol in Los Angeles and Atlanta: A contrast in secondary organic aerosol. Geophys. Res. Lett. 2011, 38. [CrossRef]

72. Krecl, P.; Hedberg Larsson, E.; Ström, J.; Johansson, C. Contribution of residential wood combustion and other sources to hourly winter aerosol in Northern Sweden determined by positive matrix factorization. Atmos. Chem. Phys. 2008, 8, 3639-3653. [CrossRef]

73. Pachon, J.E.; Weber, R.J.; Zhang, X.; Mulholland, J.A.; Russell, A.G. Revising the use of potassium (K) in the source apportionment of $\mathrm{PM}_{2.5}$. Atmos. Pollut. Res. 2013, 4, 14-21. [CrossRef]

74. Schauer, J.J.; Kleeman, M.J.; Cass, G.R.; Simoneit, B.R.T. Measurement of emissions from air pollution sources. 5. C-1-C-32 organic compounds from gasoline-powered motor vehicles. Environ. Sci. Technol. 2002, 36, 1169-1180. [CrossRef]

75. Brown, S.G.; Frankel, A.; Hafner, H.R. Source apportionment of VOCs in the Los Angeles area using positive matrix factorization. Atmos. Environ. 2007, 41, 227-237. [CrossRef]

76. Fraser, M.P.; Cass, G.R.; Simoneit, B.R.T. Gas-phase and particle-phase organic compounds emitted from motor vehicle traffic in a Los Angeles roadway tunnel. Environ. Sci. Technol. 1998, 32, 2051-2060. [CrossRef] 